Georgia State University

ScholarWorks @ Georgia State University

\title{
Explaining property tax collections in developing countries: the case of Latin America
}

\author{
Cristian Sepulveda \\ Tulane University of Louisiana, cristian.sepulveda@farmingdale.edu \\ Jorge Martinez-Vazquez \\ Georgia State University, jorgemartinez@gsu.edu
}

Follow this and additional works at: https://scholarworks.gsu.edu/econ_facpub

Part of the Economics Commons

\section{Recommended Citation \\ Cristian Sepulveda and Jorge Martinez-Vazquez, Explaining property tax collections in developing countries: the case of Latin America, in G. Brosio and J.P. Jimenez (eds.) Decentralization and Reform in Latin America: Improving Intergovernmental relations. Chetelham: Edward Elgar. 2012}

This Book Chapter is brought to you for free and open access by the Department of Economics at ScholarWorks @ Georgia State University. It has been accepted for inclusion in ECON Publications by an authorized administrator of ScholarWorks @ Georgia State University. For more information, please contact scholarworks@gsu.edu. 


\section{Decentralization and}

Reform in Latin

America

Improving Intergovernmental Relations

Edited by

Giorgio Brosio

University of Turin, Italy

Juan Pablo Jiménez

Economic Commission for Latin America and the Caribbean (ECLAC) and School of International and Public Affairs (SIPA), Columbia University, USA

IN ASSOCIATION WITH THE ECONOMIC COMMISSION FOR LATIN AMERICA AND THE CARIBBEAN (ECLAC)
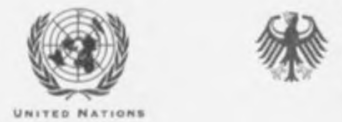

Federal Ministry

for Economic Cooperation and Development

\section{E C L A C}

\section{Edward Elgar}

Cheltenham, UK • Northampton, MA, USA 
All rights reserved. No part of this publication may be reproduced, stored in a retrieval system or transmitted in any form or by any means, electronic, mechanical or photocopying, recording, or otherwise without the prior permission of the publisher.

Published by

Edward Elgar Publishing Limited

The Lypiatts

15 Lansdown Road

Cheltenham

Glos GL50 2JA

UK

Edward Elgar Publishing, Inc.

William Pratt House

9 Dewey Court

Northampton

Massachusetts 01060

USA

A catalogue record for this book

is available from the British Library

Library of Congress Control Number: 2012939927

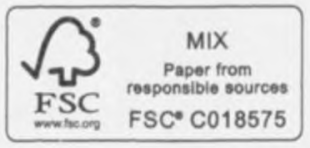

ISBN 9781781006252

Typeset by Servis Filmsetting Ltd, Stockport, Cheshire Printed and bound by MPG Books Group, UK 


\title{
7. Explaining property tax collections in developing countries: the case of Latin America
}

\author{
Cristian Sepulveda and \\ Jorge Martinez-Vazquez*
}

\section{INTRODUCTION}

The property tax is arguably the most important source of own revenues for local governments around the world. Many fiscally decentralized economies as well as an increasing number of countries that have embarked upon a decentralization process look at the property tax as the main source of revenue autonomy for their subnational governments. This practice is well matched with policy principles. There is widespread agreement among economists and decentralization experts that, although not entirely perfect, the property tax possesses several characteristics that are desirable in the context of subnational government finance.

Besides its theoretical advantages, however, in practice all is not well with the property tax. It is difficult to implement, costly to administer, and unpopular among taxpayers. It is well known that many countries around the world struggle to produce any significant amounts of revenue from this tax source. These difficulties are more prevalent among developing countries and, particularly in Latin America, the property tax continues to be a predominant policy concern among policy makers. With very few exceptions, Latin American countries have not been able to develop revenue-productive property tax systems. Moreover, Latin America has been identified in the economic literature as a region with relatively low tax effort (Bird et al., 2006), and with a level of tax revenue performance that is lower than the average in developing and transition countries (Ahmad and Brosio, 2008; Bird et al., 2008). The problems of low tax effort and revenue performance are especially acute and challenging in the case of the property tax.

The main objective of this chapter is to analyze the causes of the poor tax performance of the property tax in Latin America and to identify 
policies that could help with the current impasse. Part of what we find is conventional wisdom. The lack of financial and technical means to assemble accurate, comprehensive and updated cadastres (property registers) is clearly one of the main reasons explaining the lackluster performance of the property tax. In fact, there is an extensive literature addressing these issues and suggesting more feasible alternatives to the assessment of property values. All these lessons are relevant to Latin America and they should be internalized by policy makers. But we also arrive at less conventional findings. Previous analyses of the performance of the property tax have given much less attention to the design of the fiscal decentralization system within which the property tax must operate. The arrangement of fiscal incentives in the decentralization system, we contend, can also play a crucial role in determining the extent to which the property tax is used in practice. We argue that the realignment of fiscal incentives must be an important part of the solution for a more effective use of the property tax in the region.

We emphasize the mutual dependence between a sound fiscal decentralization process and the successful devolution of the property tax to local governments. In order to become a productive revenue source, the decentralization of the property tax also requires that local authorities be politically accountable to their communities, be endowed with a significant degree of fiscal autonomy, face the correct incentives within the context of central government policies, and have sufficient administrative capacity to carry out tax and expenditure policies.

A few words on the scope of the chapter are in order. The concept of property is a broad one, encompassing different forms of wealth over which different taxes can be applied. In general, we can differentiate between real or immovable property, which includes land and structures, from personal property, consisting of those tangible and intangible assets that are not attached to the land. In addition, taxes can be applied to the stock of properties, their transfer, or the capital gains realized on their sale. This chapter focuses on the annual taxation of the stock of immovable property, which is generally considered among the most efficient modes of property taxation and constitutes the bulk of property tax revenues around the world. ${ }^{1}$

In this chapter we also distinguish between the analysis of property tax collections at the subnational level within a country and that across countries. We explain that certain variables that are exogenous for subnational governments within a country, such as the legal and institutional frameworks, are likely to be endogenously determined at the country level, and thus they should also be considered as components of the national tax effort. Unfortunately, the information available at the subnational 
government level is, in general, still very limited, so the econometric analysis tends to be more informative at the international level. Moreover, even in that case, the data available for Latin American countries are quite incomplete, which naturally limits the validity of our results. Our dataset consists of an unbalanced panel of nine countries with years of observation covering the 1990-2007 period.

We suggest that the improvement of property tax collections and the realization of effective revenue autonomy may require, paradoxically, a more active involvement of the central government in the implementation, administration and collection of the property tax. The central governments in the region might provide technical and financial assistance to the less administratively developed local governments, and in some cases might temporarily retain some responsibilities over different aspects of this revenue source. In addition, the central government could contribute by helping to strengthen the relationship between autonomy and accountability at the subnational level, and by redesigning the intergovernmental transfer systems in a way that does not provide incentives to reduce subnational own-tax collections.

The rest of the chapter is organized as follows. In Section 2, we provide an overview of the main characteristics and importance of the property tax in Latin America. In Section 3 we evaluate the property tax in terms of the desirable properties of a good subnational tax. In Section 4 we develop an analytical framework in which we identify the determining factors of tax collection performance of subnational governments. This analytical framework provides a sounder basis for the comparison of performances of subnational governments within a country and across different countries, where performance is measured on the basis of actual revenue collections vis-à-vis the potential collections reflected by existing fiscal capacities. In Section 5 we present the empirical analysis. The last section concludes.

\section{PROPERTY TAXATION IN LATIN AMERICA}

Despite the generally accepted potential of property taxes in tax systems all over the world, in practice they are a minor source of public revenues, specially by comparison to other taxes also commonly used worldwide such as income taxes, VAT or sales taxes. The property tax is especially far from being a mainstay of the revenue system in developing and transitional countries.

To put the performance of property taxes in Latin America into perspective, we compare it with the performance of other regions of the 
Table 7.1 Property tax as a share of GDP in representative groups of countries (\%)

\begin{tabular}{lcccc}
\hline & $1970 \mathrm{~s}$ & $1980 \mathrm{~s}$ & $1990 \mathrm{~s}$ & $2000 \mathrm{~s}^{*}$ \\
\hline All countries & 0.77 & 0.73 & 0.75 & 1.04 \\
(number of countries) & $(37)$ & $(49)$ & $(59)$ & $(65)$ \\
OECD countries & 1.24 & 1.31 & 1.44 & 2.12 \\
(number of countries) & $(16)$ & $(18)$ & $(16)$ & $(18)$ \\
Transition countries & 0.34 & 0.59 & 0.54 & 0.68 \\
(number of countries) & $(1)$ & $(4)$ & $(20)$ & $(18)$ \\
Developing countries & 0.42 & 0.36 & 0.42 & 0.60 \\
(number of countries) & $(20)$ & $(27)$ & $(23)$ & $(29)$ \\
Latin American countries & - & - & 0.36 & 0.37 \\
(number of countries) & - & - & $(8)$ & $(10)$ \\
\hline
\end{tabular}

Note: Figures in parentheses represent the number of countries considered in each computation.

* The data for 2000 s are for five years from 2000 to 2004.

Sources: Bahl and Martinez-Vazquez (2008) and CEPAL.

world. As shown in Table 7.1, property taxes in developing and transitional countries raise less revenue relative to GDP than OECD countries. In the early 2000 s property taxes in OECD countries represented 2.12 percent of GDP, while for developing countries this figure was 0.6 percent and, for transition countries, 0.68 percent. The trend for revenues in all three groups of countries has been slightly upwards since the 1970s. The figures in Table 7.1 suggest that the overall performance of the property tax in terms of GDP is associated with the level of economic development; for example, OECD countries rely more on the property tax than do developing countries. However, that relationship is not necessarily monotonic and Latin American countries are found to perform less well than the average developing country.

Table 7.2 presents the measures of property tax performance for some Latin American countries. Even though the reliance on the property tax is low, there is still a significant degree of variation across countries. For example, in Peru property tax revenues in recent years (2005-07) represent 0.16 percent of GDP, while in Bolivia (Plurinational State of) for the same period that figure is about four times larger, at 0.62 percent of GDP. There is no clear trend over time but on average the relative importance of property taxes has decreased. There are also some cases where property tax performance has consistently increased over time, such as in Brazil, Colombia, Ecuador and Guatemala; while in Mexico property 
Table 7.2 Reliance on the property tax as a share of GDP in Latin American countries

\begin{tabular}{lcccc}
\hline & $1990-94$ & $1995-99$ & $2000-04$ & $2005-07$ \\
\hline Argentina & 0.65 & 0.62 & 0.59 & 0.44 \\
Bolivia (Plurinational State of) & - & - & 0.69 & 0.62 \\
Brazil & 0.37 & 0.41 & 0.42 & 0.44 \\
Chile & 0.55 & 0.65 & 0.70 & 0.59 \\
Colombia & 0.25 & 0.46 & 0.48 & 0.54 \\
Ecuador & 0.10 & 0.13 & 0.13 & 0.14 \\
Guatemala & 0.09 & 0.07 & 0.14 & 0.16 \\
Mexico & 0.18 & 0.18 & 0.18 & 0.18 \\
Paraguay & - & 0.36 & 0.39 & - \\
Peru & - & - & 0.17 & 0.16 \\
Uruguay & 0.52 & 0.70 & 0.71 & - \\
Latin American countries & 0.33 & 0.40 & 0.38 & 0.36 \\
\hline
\end{tabular}

Source: CEPAL.

taxes have represented 0.18 percent of GDP, without changing since the early 1990s.

Central to this chapter is the question of which factors may help explain variations in the use of property taxes in Latin America. It seems quite certain that property taxes remain the great unrealized promise for local tax autonomy. Like in some other regions of the world, the yield of the property tax remains lower than its potential; but in Latin America the distance between potential and reality appears to be much larger, and the reasons for this are multiple. In this chapter we explore several of these, including low political will and disincentive effects of revenue sharing and transfers, and outdated and poorly equipped tax administrations. These factors would seem to translate into generous exemptions and low tax rates, obsolete and infrequent property value assessments, incomplete registries and cadastres and lack of willingness and means of enforcing collections.

This lackluster performance of property taxes in Latin America and the differences observed among countries are likely to be related to the different arrangements for discretion on rate setting or administration of the property tax. Some of the main institutional features in the assignment and administration of the property tax across Latin American countries are presented in Appendix Table 7A.1. ${ }^{2}$ For the most part, Latin American countries assign the property tax to municipal governments, although there are 'full' exceptions such as the case of the Dominican 
Republic where this tax remains a central tax, and 'partial' exceptions where some authority over taxes remains at the central level (for example, Brazil for rural taxes, Guatemala, and Panama) or at the provincial level (Argentina). In most cases, municipalities are also given some authority to change tax rates, at times within legislated limits, but here there are also exceptions. For example, Chile does not give that authority to the municipalities, and the states or provinces in Mexico and Argentina also share in that authority. For the administration of the tax, the central governments (the provinces in the case of Argentina) are most frequently responsible for updating the cadastre; in Costa Rica, Honduras, and Mexico the cadastre is a municipal function. In terms of assigning the responsibility for billing and collections there are a large variety of practices with these functions at times exclusively assigned to the central or municipal governments and other times shared by different levels of government. Finally, the predominant approach to the assessment of properties is market valuation.

A priori, we can theorize on the positive and negative aspects of the assignment of specific functions vis-à-vis the revenue productivity of property taxes. For example, the assignment of administrative functions at the municipal level may have certain advantages, such as better information about the properties and potentially stronger incentives to collect taxes, but the central authorities might also have advantages, such as betterskilled and better-remunerated officials and stronger authority to make things happen. In the next section we explore in more depth the role of property taxation in financing local governments and the advantages and disadvantages of different administrative schemes. Ultimately, we shall rely on our empirical analysis to discern the direction and statistical significance of the effects of different administrative arrangements on tax collections from the property tax.

\section{THE ROLE OF PROPERTY TAXATION ON LOCAL GOVERNMENT FINANCING}

There is widespread agreement among economists and policy makers about the appropriateness and convenience of assigning the property tax to local governments. Indeed, while the theoretical normative analyses developed in the economic literature suggest that the property tax is a good source of local government revenue, in practice most of the decentralized economies in the world have assigned, at least partially, the responsibility over the property tax to local governments. This matching of theory and practice, however, does not imply that the decentralization of the property tax has always been carried out in accordance with the 
normative prescriptions developed in the economic literature. In many cases, either because of the difficulties associated with its implementation, or because of poorly designed incentives, the property tax has not become a significant source of revenues.

The economic role currently assigned to property taxation has been shaped by a vast and longstanding literature analyzing the advantages and disadvantages of alternative tax revenue sources. In this section we briefly describe the economic arguments used to recommend the property tax as one of the major sources of own local government revenues. We start by discussing the general characteristics of good tax revenue sources, in general and at the local level, and then we briefly stress the importance of tax revenue autonomy in a decentralized system of government.

\section{A Preliminary Evaluation of Subnational Property Taxation}

Tax policy is carried out in complex environments where institutional, cultural, political, and economic variables interact in order to determine not only the economic effects of certain tax instruments, but also their feasibility as policy tools. In reality, there are no easy answers regarding the desirability of one tax instrument over another, and economists usually rely on a set of widely accepted criteria or principles in order to describe a 'good tax' and evaluate the appropriateness of alternative tax instruments. Among the most commonly used principles we find the following:

- Efficiency A tax should not induce significant behavioral responses of individuals and firms; in other words, it should not distort the adequate allocation of resources in the economy. When taxpayers bear their burden in accordance with the benefit they receive (that is, when the 'benefit principle' is fulfilled) then the tax approximates the role of a user fee and is considered as an efficient tax. Indeed, the behavioral responses induced by (rightly set) user fees can be interpreted as the result of a correcting incentive (similar to what happens in private markets), because the adjustment in the behavior of the individual or the firm is made in order to pay the correct price of the public good.

- Equity and fairness The principle of horizontal equity calls for (or regards as fair) an equal treatment of taxpayers in identical conditions. In contrast, the concept of vertical equity allows for several possible arrangements in which a tax can be said to be regressive, proportional or progressive as long as the tax burden increases in a lower, equal or higher proportion with the ability to pay. The ability-to-pay principle states that taxpayers with greater ability to 
pay should bear a greater tax burden, but the judgment on what is to be considered fair is a matter to be solved by each community or society. In any case, in order to become a good revenue source, a tax should be considered fair by the taxpayers.

- Revenue adequacy A tax should raise a significant amount of revenues relative to the costs of collection and expenditure needs of a government. In addition, the tax base should be stable and rather insensitive to cyclical fluctuations.

- Low costs of administration and compliance Administration costs reduce the share of tax collections available to finance public goods and services. Similarly, compliance costs reduce the share of taxpayers' income available 'for private consumption. If these costs are relatively high then other tax revenue sources might be preferable.

- Political acceptability A tax that is not acceptable either to the taxpayers or to a significant portion of the political class might simply be impossible to implement. Even if it is implemented, in order to be successful, a tax requires a high degree of cooperation of all relevant agents and institutions. Failing to reach this cooperation might result in low voluntary compliance, inadequate or unrealistic laws, and deficient enforcement.

- Minimize tax avoidance and tax evasion A tax should not induce significant, legal or illegal, efforts to elude the tax burden. Both types of responses erode the tax base, create deviations from the targeted incidence, distort the relative prices in the economy and might aggravate problems in horizontal and vertical equity.

No tax instrument perfectly fulfills all these principles nor could it be considered as superior to all alternative tax instruments in all conditions. In reality, although these principles of taxation serve as a guide to describe the characteristics of a 'good' tax instrument, they must be evaluated in the specific context where a tax is implemented. A general evaluation of the property tax, therefore, can be expected to lead to different conclusions depending on its structure, whether the property tax is assigned to the central government or to the local governments, and so on.

Table 7.3 summarizes the relative advantages and disadvantages of assigning the property tax to the central or to the local governments. ${ }^{3}$ Local governments have an advantage in terms of economic efficiency because their proximity to the taxpayers allows them to better fulfill the benefit principle. Indeed, the central government is more subject to the 'common pool problem', by which those who contribute to financing the public goods (the country as a whole if the tax is assigned to the center) are not necessarily the beneficiaries of public expenditures. In general, the 
Table 7.3 Comparative analysis of property taxation at the central and local levels of government

\begin{tabular}{|c|c|c|}
\hline Principle & $\begin{array}{l}\text { Property tax as a central } \\
\text { government tax }\end{array}$ & $\begin{array}{l}\text { Property tax as a local } \\
\text { government tax }\end{array}$ \\
\hline Efficiency & $\begin{array}{l}\text { Disadvantage: the } \\
\text { 'common pool } \\
\text { problem' increases } \\
\text { with the size of the } \\
\text { government }\end{array}$ & $\begin{array}{l}\text { Advantage: the property } \\
\text { tax approximates a user } \\
\text { fee, especially as the } \\
\text { jurisdiction size decreases }\end{array}$ \\
\hline Equity and fairness & $\begin{array}{l}\text { Advantage: both vertical } \\
\text { and horizontal } \\
\text { disparities can be } \\
\text { addressed at a national } \\
\text { level }\end{array}$ & $\begin{array}{l}\text { Disadvantage: } \\
\text { heterogeneity and different } \\
\text { tax bases impose unequal } \\
\text { conditions in different } \\
\text { jurisdictions }\end{array}$ \\
\hline Revenue adequacy & $\begin{array}{l}\text { Advantage: less mobility } \\
\text { and variability at the } \\
\text { national level }\end{array}$ & $\begin{array}{l}\text { Disadvantage: revenues can } \\
\text { be more volatile in smaller } \\
\text { jurisdictions }\end{array}$ \\
\hline $\begin{array}{l}\text { Low administration } \\
\text { costs }\end{array}$ & $\begin{array}{l}\text { Advantage: better } \\
\text { administrative and } \\
\text { fiscal capacity }\end{array}$ & $\begin{array}{l}\text { Disadvantage: } \\
\text { implementation costs } \\
\text { might simply be }\end{array}$ \\
\hline & $\begin{array}{l}\text { Disadvantage: economies } \\
\text { of scale might not be } \\
\text { substantial }\end{array}$ & $\begin{array}{l}\text { unaffordable } \\
\text { knowtage: first-hand } \\
\text { taxpayers and the tax base }\end{array}$ \\
\hline $\begin{array}{l}\text { Low compliance } \\
\text { costs }\end{array}$ & \multicolumn{2}{|c|}{$\begin{array}{l}\text { (Depend on the complexity of the system and the } \\
\text { taxpayers' willingness to contribute) }\end{array}$} \\
\hline Political acceptability & $\begin{array}{l}\text { Disadvantage: the } \\
\text { property tax is very } \\
\text { visible }\end{array}$ & $\begin{array}{l}\text { Advantage: visibility } \\
\text { helps to link taxation with } \\
\text { public goods benefits and } \\
\text { increases accountability }\end{array}$ \\
\hline Tax compliance & $\begin{array}{l}\text { Disadvantage: inflexible } \\
\text { terms and 'common } \\
\text { good problem' } \\
\text { reduce willingness to } \\
\text { contribute }\end{array}$ & $\begin{array}{l}\text { Advantage: closer match of } \\
\text { taxpayers' preferences and } \\
\text { better knowledge of their } \\
\text { ability to pay }\end{array}$ \\
\hline
\end{tabular}

Source: Authors' elaboration.

lower the size of the jurisdiction and the greater the share of the property tax on local revenues, the greater the ability of local governments to use property taxation as a benefit tax.

The central government seems to have a clear advantage in terms of the ability to address the problems of horizontal and vertical equity and 
fairness. Since Musgrave (1959) the economic literature distinguishes macroeconomic stability, an equitable distribution of income and the efficient allocation of resources as the three fundamental economic objectives of the (general) government, and broadly accepts that local involvement should be restricted only (or mostly) to contribute to the objective of allocation efficiency. The reason is that local authorities cannot consider the macroeconomic consequences of their decisions, nor are they capable of, or interested in, ensuring fairness in the national context. According to this argument, local governments should not even intervene in redistributive policies within their own jurisdictions, but rather might limit themselves to avoiding worsening the distribution of income at the local level. ${ }^{4}$ This consideration is éspecially relevant in Latin America, a region where the distribution of income is among the worst in the world (Lopez and Perry, 2008). ${ }^{5}$

Independently from the relative magnitude of property tax collections, the fact that mobility is lower at the national level implies that the property tax collections would be more stable for the central government. At the local level individual taxpayers can move out as a response to excessive tax rates and lower the market value of properties. Firms might also decide to leave the jurisdiction and in that case, in addition to the property value effect, the loss in tax collections would be greater if commercial use is taxed more heavily than residential use.

Due to their potentially significant magnitude, the administration costs play a crucial role in determining the ability of a government to adequately implement and collect the property tax. In particular, the assessment of property values is complex and requires well-prepared personnel; building a complete cadastre is a long and expensive task. In this context the central government usually has advantages in terms of its ability to finance and develop comprehensive cadastres. Moreover, local authorities in developing countries usually lack the enforcement mechanisms available to central governments, such as legal staff, the police, and other means to take advantage of their proximity to tax officials and taxpayers.

Importantly, local property taxation might also have an advantage in terms of the political acceptability. One payment (or a few) per year of a relatively large amount of money makes the property tax a visible and an unpopular revenue source. Local authorities are in a better position than the central government to show the taxpayers the way in which property tax revenues are used to finance public services, and therefore to justify the tax payments as a fair price for the benefits received. If local authorities manage to effectively match public service provision with the preferences of the community, then the taxpayers might well feel inclined to voluntarily comply with the tax law, reducing the practice of tax evasion. In this 
sense, an adequate supply of public services might provide incentives to taxpayers to remain in the jurisdiction even if tax rates are relatively high with respect to neighboring areas. The local authorities also have a better knowledge of the taxpayers' ability to pay inside the jurisdiction; thus they might be able to better monitor and enforce compliance as well as make proper adjustments to the local tax policy. Torgler (2005b) finds that the size of the informal sector is an important determinant of tax compliance in Latin America. The informal sector represents an important share of the economy in developing countries, and in Latin America is estimated to be around 41 percent of the GNP (Alm and Martinez-Vazquez, 2007). The question is whether local governments can exploit their advantage of being 'closer' to the constituencies in order to bring more activities into the formal sector and encourage increased voluntary compliance. Little research has been done on this issue.

In summary, both central and local governments have advantages and disadvantages for administering the property tax, and it is not possible to assert a priori which level will perform better. In practice, however, their strengths can be combined in mixed arrangements of authority and responsibilities. On the one hand, the visibility of the property tax, usually considered as a disadvantage for the central government, is a key aspect of the problem that calls for a keen participation of local authorities in rate setting and also in the administration of the property tax. At the local level the tax authorities might be able to use such visibility to present the property tax as a benefit tax, enhancing political acceptability and taxpayers' participation in local decisions, and potentially reducing non-compliance. On the other hand, central government intervention might be helpful to develop comprehensive cadastres, to assist in the formation of administrative capacity and to provide policy parameters within which the creation of inefficiencies can be contained.

The literature has identified a number of additional desirable features of a 'good local tax'. ${ }^{6}$ Among these features we count, again, the correspondence between tax payments and benefits received (benefit principle), the perception of fairness, and the stability of revenue collections. In addition, and pondering some of the arguments provided earlier in this section, the visibility of the tax instrument is considered as a good characteristic of local taxation. Other desirable features that are applicable specifically within the local context are:

- The tax base should be relatively immovable According to the Tiebout's (1956) hypothesis, taxpayers would 'vote with their feet' and efficiently reallocate themselves after considering the combination of taxes and services offered by different local governments. 
In practice, however, tax competition among subnational governments might also lead to a 'race to the bottom', if local governments are forced to reduce their tax rates in order to retain the taxpayers inside the jurisdiction. As a result, the overall amount of subnational public expenditures may remain at a suboptimal level. ${ }^{7} \mathrm{~A}$ consensual, but rather conservative, position to deal with the unclear effects of mobility in economic efficiency consists of assuming that any fiscally induced change in taxpayers' behavior represents a distortion of the efficient allocation of resources in the economy and consequently reduces economic welfare. Moreover, it is clear that a relatively immovable tax base would allow for more room in tax policy decisions.

- The tax should be geographically neutral Taxes should not interfere with the commercial flow of goods and services and business location decisions across the jurisdictions. In this case we again assume that tax-induced changes of taxpayers' behavior should be avoided.

- Taxes should not be easily exported The benefit principle does not hold if non-residents are charged for the provision of local services. In addition, such a situation implies that the costs assumed locally are reduced, which might also lead to overprovision of public services.

- Significant tax revenue sources should be evenly distributed among jurisdictions Sizable variations in the size of the tax base create high fiscal disparities among jurisdictions and impose undesirable differences in the degree of revenue autonomy. In general, local governments with more (less) revenue autonomy are also able to exert more (less) discretion in their expenditure decisions, and this might translate into greater (lower) ability to tailor the public service provision to the preferences of the community. Great differences in the size of the tax base, therefore, might generate discontent and even confusion regarding the importance of own-revenue collections and, in general, the role of local governments in a decentralized system.

The extent to which these conditions hold, or are adhered to in practice, is likely to vary from one tax instrument to another. In general, it seems reasonable to expect that only some taxes, if any, will satisfy all of them. For instance, there are few taxes that satisfy the benefit principle and are not exportable, among which the property tax and the $\operatorname{tax}$ on vehicles stand as the most typical examples. However, both of these are subject to tax competition, which can create economic inefficiencies and erode the tax bases. In addition, in most cases the magnitude of the tax base varies significantly across jurisdictions, particularly between urban and 
rural areas. In this sense, we can also expect a certain degree of correlation between the size of the tax base and the administrative capacity of the local government, such that the initial disparities are aggravated by the relative difficulties in raising local revenues.

All things considered, the property tax represents a promising but still imperfect source of own revenues at the local level. Even with significant decentralization of the property tax, poorer local governments will likely remain dependent on alternative sources of revenues, notably intergovernmental transfers. In addition, special attention will be required to create a tradition of taxpayers' participation and voluntary compliance, and to provide the right incentives for efficient levels of tax effort by local governments.

\section{The Importance of Tax Revenue Autonomy}

The decentralization theorem (Oates, 1972) states that if the decisions about the type and amount of public goods are allowed to be made locally, then the level of social welfare would be greater with respect to a situation where public goods are centrally, and uniformly, determined for all localities. The reason is simply that the local governments are better able to tailor public goods provision to the particular needs and preferences of each jurisdiction. ${ }^{8}$

In order to adapt the type and amount of public goods to local needs and preferences, the local authorities require, by necessity, a certain degree of autonomy on their expenditure decisions. But even if granted by law, the expenditure autonomy cannot be practiced without sufficient technical and administrative capacity and the ability to discretionally increase the amount of local revenues. The existence of effective expenditure and revenue autonomy is widely recognized in the literature as a basic requirement for realizing the welfare gains of fiscal decentralization. Unfortunately, this economic prescription does not always concur, and might even collide with, the practical drivers of decentralization. The international movement towards greater fiscal decentralization has responded more to political forces such as the demand for deeper democratization, the resolution of ethnic conflicts, or the failure of central governments in securing national objectives, than to a search for greater economic efficiency as portrayed in the decentralization theorem. ${ }^{9}$ In many countries the implementation of an economically efficient decentralization design, although desirable, might well not be a priority.

According to Ahmad and Brosio (2008), one of the main factors weakening the decentralization process in Latin America has been the lack of attention given to the subnational revenue assignments. In this context, it 
does not seem too audacious to suggest that the widespread decentralization of the property tax is partially explained by the fact that the central authorities have several more efficient, easier to administer, and less unpopular revenue sources under their control. Similarly, central authorities are usually reluctant to devolve effective autonomy to the subnational governments in most areas of taxation. The reason for this may be the lack of technical and administrative capacity at the subnational level, but it is also reasonable to presume that central authorities are not willing to renounce their power over budgetary decisions.

In short, even though the choice of the property tax as a main source of local own revenues seems to be correct from an economic perspective, the assignment of this revenue source to the local governments by no means guarantees that local governments will be able to exert expenditure autonomy in the margin and to realize the benefits of decentralization.

\section{EXPLAINING PROPERTY TAX COLLECTIONS: AN ANALYTICAL FRAMEWORK}

The amount of property tax revenues that governments are able to collect varies widely across nations and across jurisdictions within any country, and depends on a wide range of institutional, cultural, political and economic factors. The problem of property tax collections (or the lack thereof) has been extensively analyzed in the economic literature. The complexities of the problem and data limitations, however, still impose severe restrictions on the empirical analyses; as a result, no conclusive answers have been reached about the factors determining property tax collections.

In this section we develop a model of property tax collections, show their dependency on the concept of tax effort, and explain how the design and implementation of the fiscal decentralization process can affect the performance of the property tax. We begin by presenting a general model of revenue collections and then we analyze, separately, the revenue collection problem at the subnational and national levels.

\section{A Simple Model of Property Tax Collections}

Following Bahl and Martinez-Vazquez (2008), and assuming that the property value assessment is based on market value, the amount of property tax collections (TC) can be defined as: ${ }^{10}$

$$
T C=\frac{T C}{T L} \cdot \frac{T L}{T A V} \cdot \frac{T A V}{T M V} \cdot \frac{T M V}{M V} \cdot M V,
$$


where

$T L$ : property tax liability,

$T A V$ : taxable assessed value,

$T M V:$ taxable market value,

$M V$ : full market value.

The first term on the right-hand side, property tax collections over tax liability, corresponds to the collection ratio. In the ideal case the amount of tax collections should be identical to the tax liabilities and this term would be equal to one. In practice, however, either the tax authorities might fail to properly enforce the tax law or the taxpayers might fail to comply with it; thus the collection ratio is normally lower than one. The value of the collection ratio can be interpreted as a measure of the observance of the tax law and the ability of the authorities to enforce it through fines or even jail sentences. According to Bahl and Martinez-Vazquez (2008), a normal value for the collection ratio in developing countries is around 50 percent, which is explained as mainly due to lax tax enforcement, and in some cases can even be as low as 20 percent.

The second term on the right-hand side of equation (7.1), the share of tax liabilities over taxable assessed value, is the statutory tax rate, usually set at some value lower than 1 percent. The third term represents the assessment ratio, the share of taxable assessed value on taxable market value, by which the law establishes the share of the taxable market value over which the tax liability is actually going to be computed. When the assessment ratio is specified by law, then it normally takes a value between zero and one, but if it is not specified, then its implicit value is one. The assessment ratio is nothing more than an adjustment to the statutory tax rate and it is used to induce acceptability of the tax system and reduce complaints about the assessment criteria, because it gives taxpayers the impression that they are not being taxed for the full value of their property. " Finally, the fourth and fifth terms on the right-hand side of equation (7.1) jointly represent the tax base $(T B)$ that is actually available for taxation. The fourth term is the ratio of taxable market value over (full) market value, and summarizes all the effects of preferential treatments, exemptions on the tax base, and errors in assessing the true market value of the property (the last term in the equation). Equation (7.1) can now be rewritten as:

$$
T C=\frac{T C}{T L} \cdot t^{a} \cdot T B,
$$

where $t^{a}$ is the statutory tax rate 'adjusted' by the assessment ratio.

As explained, the collection ratio measures the degree of observance of 
the tax law, and can be different from one only in the presence of 'distortions' imposed by the behavior of government authorities or taxpayers. There are several possible sources of distortions that can explain a low degree of observance of the tax law. On the government side, the tax law can be deficiently enforced $(D E)$ if the tax authorities are either unable or unwilling to capture the whole revenue potential of the property tax. We might also be in the presence of corruption $(C)$, in which case the tax authorities appropriate for themselves a share of the revenues collected.

On the taxpayers' side, revenues might be lost due to tax evasion $(E)$, generally defined as any illegal form of taxpayers' non-compliance. ${ }^{12}$ The traditional model of tax evasion explains taxpayers' non-compliance by considering the probability of auditing and detection, the cost of enforcement and the costs of non-compliance, which can be summarized under the concept of penalties $(P) \cdot{ }^{13}$ In the case of the property tax, however, illegal non-compliance is limited by the very nature of the tax base. If properties are immovable, then they cannot easily be hidden from the tax authorities. As a result, tax evasion can take place only under certain circumstances. For instance, the taxpayers might take advantage of the inability or unwillingness of the tax authorities to correctly assess the value of the property, or might also attempt to lie in order to qualify for preferential treatments and exemptions. In these cases the factor explaining tax evasion is deficient enforcement. Alternatively, corrupt tax authorities might accept bribes for reducing taxpayers' tax bills.

Another possible form of tax evasion consists of simply refusing to pay the tax liabilities. This decision would be economically rational and even become a common practice, if taxpayers perceive that the tax law is not enforced or if the costs of tax evasion are relatively low. In contrast, if the tax law specifies high penalties and is being properly enforced, then tax evasion would certainly be too costly and eventually lead to the expropriation of the property; thus it is less likely that the taxpayers would choose this strategy.

The economic literature has recently incorporated the concept of tax morale $(T M)$ in order to account for the fact that taxpayers are usually inclined to voluntarily comply with the tax law even in the absence of effective enforcement. ${ }^{14}$ Analyzing opinion survey data from the United States and Turkey, Torgler et al. (2008) find that positive attitudes towards the tax authorities and the tax system as well as trust in public officials significantly increase tax morale, while the perception of corruption has the opposite effect. Additionally, Torgler (2005a) shows that the willingness to pay taxes increases with the level of direct democracy in a jurisdiction. The evidence provided by the tax morale literature suggests, therefore, that tax evasion also depends on the taxpayers' perception about the behavior and 
performance of the tax authorities, and the extent to which they conform to the preferences of the community. In our model we summarize these determinants of tax morale with the concepts of corruption and government responsiveness $(R)$. Tax morale is expected to decrease (and tax evasion to increase) with a higher perception of corruption; the opposite would occur if the tax authorities are truthfully responsive to the preferences of the taxpayers.

Summarizing, tax evasion can be said to respond positively to deficient enforcement and negatively to the size of penalties and tax morale, and we can write in shorthand that $E=E[D E, P, T M(C, R)]$. Furthermore, the amount of tax liabilities $(T L)$ can be decomposed into the observance of the tax law, represented by tax collections $T C$, and the non-observance of the tax law, represented by the tax revenues forgone due to deficient enforcement $D E$, corruption $C$, and tax evasion $E$ :

$$
T L=T C+D E+C+E[D E, P, T M(C, R)] .
$$

Solving this equation for $T C$ and dividing by $T L$, we can introduce it into equation (7.2) to express the amount of tax collections as:

$$
T C=\left\{1-\frac{D E}{T L}-\frac{C}{T L}-\frac{E[D E, P, T M(C, R)]}{T L}\right\} t^{a} \cdot T B,
$$

where tax collections appear to be a function of deficient enforcement, corruption, penalties of tax evasion, government responsiveness, the adjusted statutory tax rate, and the size of the tax base. The analytical advantage of equation (7.4) is that now tax collections are exclusively expressed as a function of exogenous variables, which allows us to more easily identify the factors that determine the actual amount of tax revenue collections.

The amount of taxes a government is able to collect largely depends on policy variables that can be influenced either by the tax law or by the tax authorities. This conclusion stresses the role of the tax laws and the responsible government authorities as opposed to the role of taxpayers in explaining tax collections. A government in need of rising additional revenues is not limited to legally determining the tax rate and the tax base. In reality, several alternative channels might serve the same purpose. For instance, the tax law might incorporate measures to minimize and sanction corruption, set adequate levels of penalties for evasion, and restrict preferential treatments and exemptions. Alternatively, the tax authorities might choose to effectively enforce the tax law, improve the assessment process in order to more accurately measure the tax base, and to deepen the involvement of taxpayers in the public spending decisions. As De Cesare $(2002$, p. 11) 
points out in the context of a review of several independent experiences in Latin America, "it [is] clear that the political will is the principal element for explaining differences in the performance of property taxes'.

So far the discussion about the basic determinants of tax collections has not distinguished between the levels of government responsible for collecting the property tax. This distinction is important because different levels of government are given different responsibilities and decision-making powers, and also because typically they possess dissimilar levels of administrative capacity. In principle, the more discretion a subnational government is allowed, the greater the influence it can exert on the variables determining the amount of tax collections. In any case, equation (7.4) also shows that even with limited power over the design of the tax policy, a subnational government has a wide variety of channels available to alter the amount of tax collections. Indeed, due to their proximity to the collection process and to the taxpayers, the subnational authorities could enjoy some advantages with respect to the central government. Corruption, for instance, might be easier to detect and correct at the local level; strengthening the enforcement of the law and reducing tax evasion might well be facilitated by enhancing the taxpayers' participation in local expenditure decisions. Although not conclusive, the economic literature provides some evidence suggesting that fiscal decentralization reduces the level of corruption in a country. When authorities enjoy a significant degree of autonomy they not only have more ability to correct the distortions that reduce the level of tax collections, but they also are more accountable to the community. ${ }^{15}$

\section{Comparing Tax Collection Performance at the Subnational Level}

A subnational government responsible for collecting certain taxes would likely have some degree of discretion over several, and maybe all, of the explanatory variables described in equation (7.4). In this context, tax performance can be evaluated by comparing the amount of taxes collected by different subnational governments under similar conditions. A good (poor) level of performance would consist in collecting a relatively high (low) amount of tax revenues with respect to other subnational governments that face a comparable tax base and enjoy a similar level of discretion.

The natural question is what amount of tax collections should be considered as the benchmark to distinguish between good and poor performance. In principle, for each level of government, the total amount of revenues raised should be able to cover all the expenditure needs. Therefore, in a decentralized system of government the benchmarking 
amount of tax collections can be defined, jointly for all tax instruments available, as the share of expenditure needs that remain unfunded after the vertical imbalance has been corrected via intergovernmental transfers. Unfortunately, this benchmark requires a precise measure of the vertical imbalance, which in practice is difficult to obtain. A more feasible alternative is to set the benchmark at the average effective tax rate, $\overline{t^{e}}$, such that any government whose effective tax rate is higher (lower) than the average would be said to exert a relatively high (low) 'statutory' tax effort. ${ }^{16}$

Now we can multiply both the numerator and the denominator of the right-hand side of equation (7.4) by $\bar{t}$, and rewrite the equation to describe the tax collections of any jurisdiction $i$ as:

$$
T C_{i}=\left\{1-\frac{C_{i}}{T L_{i}}-\frac{D E_{i}}{T L_{i}}-\frac{E_{i}\left[D E_{i}, P, T M_{i}\left(C_{i}, R_{i}\right)\right]}{T L_{i}}\right\} \frac{t_{i}^{a}}{\overline{t^{e}}} \cdot \overline{t^{e}} \cdot T B_{i}
$$

Note that $P$ and $\overline{t^{c}}$ are the only variables not determined inside the jurisdiction. In general, the tax law assigns different responsibilities to the different levels of government, and authority over variables such as the penalties of tax evasion might be reserved to the central government or even be an exclusive prerogative of the congress. Because of this, the penalties of tax evasion as well as any policy variables that are not under the authority of subnational governments can be considered to be determined exogenously.

On the right-hand side of equation (7.5), the product of the terms inside the bracket and the ratio of adjusted statutory tax rate over the average (benchmark) effective tax rate represents a 'relative effective tax rate', which takes a value greater than, equal to or lower than one as long as the tax rate effectively applied on the government unit $i$ is greater than, equal to or lower than the sample average. This is precisely the definition of what the economic literature refers to as the tax effort (TE) exerted by a particular government. Moreover, the product of the last two terms in the equation, the average (benchmark) effective tax rate times the tax base of the government unit $i$, describes the concept of fiscal capacity $(F C)$, which is usually defined as the amount of tax revenues that could be collected if a given level of effort were applied to the available tax base. Equation (7.5) can therefore be reduced to the following identity:

$$
T C_{i}=T E_{i} \cdot F C_{i},
$$

where the taxes collected by a government $i$ are defined as the amount of revenues obtained by applying the level of effort exerted by that government to a 'fair' measure of its potential tax revenues. 
By expressing the amount of tax collections as a function of the level of tax effort, equation (7.6) stresses the fact that, given the size of the available tax base, and a certain degree of fiscal autonomy, each subnational government is largely responsible for the amount of taxes actually collected within its jurisdiction. In this sense, tax effort is a choice variable that can be altered by voluntary decisions of subnational authorities and those of taxpayers, and therefore it can be used as a measure of tax collection performance. Equation (7.6) implies that we can estimate the tax effort of a subnational government as the ratio of its actual tax collections over its fiscal capacity:

$$
T E_{i}=\frac{T C_{i}}{F C_{i}}
$$

In order to evaluate the performance of each subnational government we only need to compare its tax effort with the tax effort of the other subnational governments of the same level. Moreover, since data about subnational revenue collections are usually available for most countries, the main challenge lies in estimating fiscal capacity.

A correct interpretation of the concept of tax effort requires a careful consideration of the actual degree of fiscal autonomy enjoyed in each jurisdiction. If all subnational governments enjoy the same degree of (significant) fiscal autonomy, then a relatively high (low) level of fiscal effort might simply suggest that the jurisdiction's residents are demanding a relatively large (small) amount of subnational services. Given that the efficiency gains of fiscal decentralization arise from tailoring the provision of public services to the needs and preferences of each community, then even a very low level of tax effort could be regarded as optimal. Indeed, if the system of intergovernmental fiscal relations is properly functioning then there would be nothing right (wrong) with a high (low) level of tax effort, and no reward (penalty) would be justified. In practice, however, and especially in the initial states of a fiscal decentralization reform, subnational fiscal autonomy might be limited by several factors. For instance, there might not be a longstanding tradition of taxpayers' contributions to the public sector, and thus taxpayers might not be willing to voluntarily comply with the law and nor would the tax authorities be willing to enforce it. Decentralization reform, in this sense, can actually imply a radical cultural change for some communities. Another limitation, very common among poor jurisdictions, is that of the lack of technical and administrative capacity to manage subnational finances and collect the taxes. A subnational government cannot be expected to assess the tax base, compute the tax liability and collect the taxes without proper means to carry out these functions. But this basic contradiction is a rather 
common occurrence among subnational governments in Latin America, especially in the rural areas. In order to address this problem either an asymmetric decentralization of public functions or central government assistance to develop adequate capacity would be required.

Given that the factors limiting subnational fiscal autonomy usually affect different jurisdictions unevenly, the observed variations in tax effort and performance may no longer be the result of subnational choices. It follows that in order to make the subnational authorities (and the communities) fully liable for the differences in tax effort then they should enjoy equal, or at least comparable, levels of effective fiscal autonomy.

In spite of this argument, in order to increase own-revenue collections, some countries decide to reward high tax effort with additional intergovernmental transfers, and sanction low tax effort with no additional, or fewer, intergovernmental transfers. These incentives might serve as an effective tool to encourage greater subnational tax collections, but it is important to recognize that they would plausibly lead to counterproductive results. The reason for this is very simple and deals with the trade-off faced at the subnational level between own-revenue sources and intergovernmental transfers. Assuming that there are no savings, the total amount of government expenditures in public services $(G)$ is equal to own-tax collections plus the amount received in the form of intergovernmental transfers $(T),{ }^{17}$ thus for any subnational government $i$ we can write the budget constraint as:

$$
G_{i}=T C_{i}+T_{i}
$$

from which it is clear that subnational expenditures can be expressed as a function of intergovernmental transfers, $G_{i}=G_{i}\left[T_{i}\right]$. Replacing $T C_{i}$ by its definition in equation (7.6), dividing by fiscal capacity $F C_{i}$ and solving for the level of tax effort $T E_{i}$, we find that:

$$
T E_{i}=\frac{G_{i}\left[T_{i}\right]-T_{i}}{F C_{i}},
$$

such that the tax effort exerted by the subnational government $i$ is equal to the difference between the total amount of public expenditures and the intergovernmental transfers received, over the fiscal capacity of the jurisdiction. In other words, tax effort corresponds to the extent to which a subnational government exhausts its own tax base.

According to equation (7.9) the direct effect of intergovernmental transfers, with a negative sign, is to reduce tax effort. An additional effect, however, can be observed in the amount of public goods and services 
provided. Considering fiscal capacity as exogenous, the net effect of transfers on tax effort will depend on whether public expenditures will increase in a greater, equal or lower proportion than the transfers received. As a consequence, the final effect of intergovernmental transfers on tax effort will ultimately depend on the elasticity of public goods provision with respect to a marginal increase of the subnational budget. Jurisdictions where public goods are elastic will respond to additional intergovernmental transfers by increasing the level of tax effort, but those where public goods are inelastic, or comparatively less desirable, will reduce their tax effort. ${ }^{18}$ This implies that, regardless of the level of fiscal autonomy of subnational governments, tax effort can certainly be affected by intergovernmental transfers.

This analysis might suggest that the final effect of intergovernmental transfers on tax effort is efficient in the sense that it responds to the demand of public services within each jurisdiction. However, this conclusion is not necessarily correct. The demand for public services is affected by preferences and also by the quality of public services, and in turn this quality can be expected to vary across jurisdictions ${ }^{19}$ Some local governments might not be able to provide public services with desirable standards of quality, which would reduce their demand and the resultant level of tax effort. The obvious equity problems that arise will have to be solved in accordance with the national preferences for redistribution.

\section{Estimating Fiscal Capacity of Subnational Governments}

For the most part, the empirical literature on the property tax has focused on measuring tax effort at the subnational level by considering fiscal capacity as an exogenous factor with respect to the tax revenue performance of subnational units. The reason for this is that any exercise of discretion implies a certain degree of responsibility and thus allows us to evaluate tax performance on the basis of effective power over tax collections. In this sense, subnational governments are by presumption passive with respect to their fiscal capacity and this concept can be regarded as irrelevant for performance evaluations.

In the previous discussion we showed, however, that a good measure of fiscal capacity is critical to accurately estimate the tax effort and evaluate their tax performance. Measuring the fiscal capacity with respect to the property tax is particularly difficult because of the great financial, technical and administrative requirements for developing comprehensive cadastres of immovable properties. Any measure other than the cadastre, and independent from the actual value of properties, will provide a questionable estimation of the potential property tax base. 
Unfortunately, developing countries struggle with the complexity and costs associated with the construction of the cadastre, but still the prospect of not taxing properties seems to be a much worse solution. In practice, the use of indirect methodologies for estimating the fiscal capacity associated with the property tax can help to partially solve this problem. The literature has described a number of these methodologies, which have been designed to do as much as the availability of information allows.

One of the simplest methodologies consists of using historical property tax collections from one or several past periods. This methodology assumes that past collections can be representative of the fiscal capacity of local governments. However, there are several factors that might create a difference between potential and actual tax collections. The presence of centrally imposed exemptions eroding the tax base, or greater administrative and compliance costs, and the taxpayers' willingness to contribute to the provision of public goods, are some examples of factors that might truly reduce fiscal disparities. But historically low tax collections might also be caused by inefficiency, political favors and corruption. In this context, it is desirable to have some information about the determinants of fiscal capacity. For instance, we might expect that measures of income, production or consumption could be related to the size of the tax base, including the property tax base. In general, the use of this type of 'proxies' is preferable to the use of historical data, but in developing countries we can rarely count on this information at the local level.

There are several additional methodologies for estimating fiscal capacity and their usefulness, of course, depends on whether the data are available or not. ${ }^{20}$ In any case, it is important to stress the fact that deficient measures of fiscal capacity lead, necessarily, to equally deficient estimates of tax effort.

\section{Comparing Tax Collection Performance across Countries}

The comparison of property tax performance across countries follows the same logic as the comparison of subnational tax performance. Maybe the most important difference consists of which institutions are ultimately responsible for the relative variations in tax performance. In the analysis of subnational tax collections, subnational governments are responsible for their performance up to the point where they do not have further discretion to affect tax collections. Such a limit is imposed, for instance, by the tax law, which can usually be regarded as exogenous for any subnational government and even for the central government. In contrast, regardless of which level of government is responsible for administering a tax source, at the country level the tax law and the public policies in general should 
be considered as endogenous and other national institutions such as the congress and the judiciary system also become responsible for the resultant level of national tax performance.

In this cross-country context, most of the variables determining property tax collections can be considered to be endogenous, and we can define the total amount of tax collections for any country $j$ as:

$$
T C_{j}=\left\{1-\frac{D E_{j}}{T L_{j}}-\frac{C_{j}}{T L_{j}}-\frac{E_{j}\left[D E_{j}, P_{j}, T M_{j}\left(C_{j}, R\right)\right]}{T L_{j}}\right\} \cdot t_{j}^{a} \cdot T B_{j}
$$

where besides the change in subscripts the only difference with respect to the subnational case is that the penalties for tax evasion (as well as any other determinant that might be exogenously imposed by the tax law) are expressed as endogenous (choice) variables. ${ }^{21}$

Moreover, given that a country has full discretion to define the tax base, and provided that the market value of all land and structures $\left(V_{j}\right)$ is available for taxation in the national territory, then the share of the actual tax base over $V_{j}$ becomes by itself a component of the national tax effort. As a consequence, the country has discretion over all the variables in the righthand side of the equation, and tax effort can be defined simply as:

$$
T E_{j}=\frac{T C_{j}}{V_{j}} .
$$

This equation states that national tax effort can be estimated as the ratio between actual tax collections and the market value of lands and structures available for taxation within a country, while the last term determines the potential tax collections or fiscal capacity of the country. In turn, crosscountry comparisons can be carried out by simply comparing the values of national tax effort.

Of course, as in the case of subnational tax performance, the main challenge with estimating national tax effort is measuring the fiscal capacity of the country. If this is possible, however, the cross-country analysis of tax effort and performance offers important advantages in terms of data availability, because much more data about institutional, political, cultural and economic variables are available at the country level.

Given that each country defines its own property tax base and might use different valuation methods to estimate the tax base, a wide variation of financial and technical arrangements can be observed among different countries. As a consequence, even if available, national estimates of the property tax base are not comparable. Bahl and Wallace (2010) suggest a standardized approach in order to solve this problem: The measures of 
national wealth provided by the World Bank (2006) can be used to estimate the size of the potential property tax base under a single criterion and for a large number of countries. In Appendix Table 7A.2 we present the estimates of the potential property tax bases for a number of Latin American countries. Unfortunately, the measures of national wealth are currently available only for the year 2000 ; thus even if useful, they do not provide information about how tax bases vary across time. In the next section we use these estimates in the econometric analysis of international property tax performance.

\section{THE DETERMINANTS OF PROPERTY TAX COLLECTIONS IN LATIN AMERICA}

An empirical test of the main propositions of our analysis requires information that, in general, is not available at the subnational level in Latin American countries, so we are not able to properly account for the determinants of property tax collections at the within-country level. For this reason, we begin with a simple OLS regression analysis in order to verify how intergovernmental transfers received by local governments in Brazil and Peru (in national currency) are correlated with per capita property tax collections. ${ }^{22}$

The results are presented in Table 7.4. Because of data availability, we are able to include only a few other control variables to get a clearer picture of the potential impact of intergovernmental transfers on property tax collections. These control variables are the total amount of current revenues in each jurisdiction, revenue autonomy (defined as own taxes over total revenues), population, regional GDP in the case of Brazil, and the relative incidence of poverty and the percent of urban population in the case of Peru. We should also note that total current revenues and revenue autonomy should be expected to be endogenous with property tax collections; however, lacking valid instruments we cannot correct this problem. Nevertheless, a few interesting observations may be drawn from the results.

The most relevant result in Table 7.4 is that current intergovernmental transfers per capita are negatively and significantly correlated with property tax collections per capita in the two countries. This would seem to suggest that on average current transfers act as a disincentive for property tax collections. However, we need to interpret this result with caution. There may be an endogeneity bias in these estimates because lower property tax revenues per capita may also induce larger current intergovernmental transfers per capita. On the other hand, the coefficients of capital 
Table 7.4 Determinants of property tax collections in Brazil and Peru (dependent variable: per capita property tax collections)

\begin{tabular}{lcc}
\hline & OLS regression: Brazil & OLS regression: Peru \\
\hline Current transfers per capita & $-0.1124^{* * *}$ & $-0.2263^{* * *}$ \\
Capital transfers per capita & $(0.0237)$ & $(0.0130)$ \\
& 0.0058 & -0.0080 \\
Current revenues per capita & $(0.0063)$ & $(0.0191)$ \\
& $0.1081^{* * *}$ & $0.2165^{* * *}$ \\
Revenue autonomy (\%) & $(0.0223)$ & $(0.0123)$ \\
Per capita GDP (2000) & $2.5051^{* * *}$ & $\left(49.672^{* * *}\right.$ \\
Poverty & $(64.9611)$ & \\
& $-0.0006^{* *}$ & 0.0097 \\
Urban population (\%) & $(0.0003)$ & $(0.0427)$ \\
Population (thousands) & & $-0.1065^{* * *}$ \\
Constant & & $(0.0390)$ \\
& -0.0015 & $(0.0439)$ \\
Observations & $(0.0047)$ & 6.6278 \\
$R$-squared & $-8.7593^{* * *}$ & $(4.0486)$ \\
\hline
\end{tabular}

Notes:

Robust standard errors in parentheses.

** significant at $5 \% ; * * *$ significant at $1 \%$.

intergovernmental transfers are not statistically significant, suggesting that the distribution of this revenue source because of its unpredictability or periodicity does not affect local property tax collection performance.

The coefficients of total current revenues and revenue autonomy are positive and statistically significant. But these results are expected due to the construction of those variables; by definition the larger the property tax collections the larger will be the amount of current revenues as well as the share of own revenues in the local budgets. However, they might also suggest, subject again to a possible endogeneity bias, that local governments with larger budgets and more revenue autonomy might be better able to collect property taxes.

The regressions also include proxies for local fiscal capacity, which help to estimate the relative size of the property tax base as well as the administrative capacity of local governments. The per capita GDP variable is 
available for Brazilian local governments. Its coefficient is negative and significant at the 5 percent confidence level. This result is contrary to our expectations, as long as GDP per capita is expected to be highly correlated with the property tax base; but it could also be that a higher GDP per capita signals the availability of other tax bases, such as Brazil's ISS (local $\operatorname{tax}$ on services), which is relatively more important than the property tax in local budgets. The availability of other tax sources may push down local efforts to collect the more difficult and unpopular property tax..$^{23}$ However, we must note that the estimated coefficient is relatively unimportant in terms of magnitude, implying that property tax collections are not that responsive to this factor. In the case of Peru there are no measures of GDP at the local level. Instead, we use a measure of poverty defined as the share of the population under the poverty line; this variable displays no significant correlation with property taxes. In addition, we consider the share of the population living in urban areas, which is expected to be directly related with the size of the property tax base; however, here again the coefficient is instead negative and statistically significant, perhaps signaling the availability of other more 'convenient' revenue sources in urban areas.

Finally, the regressions also include population as a control for the jurisdiction size. In both cases the coefficient is negative, but it is significant only for Peruvian municipalities. This is somewhat surprising because we would expect to observe economies of scale in property tax collections. However, this result might be explained, for instance, by the presence of economies of scale on the expenditure side; or, alternatively, by a positive correlation between the extent of informal properties and the jurisdictional size.

The empirical analysis of property tax collections at the local level is still subject to very important data limitations, and the inability to properly control for other determinants can easily lead to significant omitted variable bias. In contrast, even though at the international level the data are also limited, there are several additional variables that allow us to control for macroeconomic, political and institutional factors that are relevant in determining property tax collections. In the end, however, there is a clear trade-off since using international cross-country data is also subject to aggregation biases and omitted country fixed effects.

The cross-country analysis of the determinants of property tax collections considers nine Latin American countries for which relevant data are partially available for the 1990-2007 period: Argentina, Bolivia, Brazil, Chile, Colombia, Ecuador, Mexico, Paraguay, and Peru. The dependent variable, property tax collections, is defined as the share of property tax collections in GDP. Based on the discussion in the previous section, we 
expect property tax collections to decrease with deficient enforcement, corruption, tax evasion and the predominance of transfers, and to increase with the size of the property tax base, government responsiveness, and the average tax rate. Even though there are direct measures of all these variables, some of them are not available for long periods of time for all Latin American countries. In order to maximize the number of observations, we use alternative (more common) variables as proxies of our variables of interest.

We consider a variety of factors accounting for the design of fiscal arrangements, the level of development, the size of the property tax base, relevant differences in the implementation of the property tax, and basic characteristics of the political system. ${ }^{24}$ The structure of fiscal arrangements is described through measures of fiscal decentralization, the level of transfer dependency, and the size of government. Fiscal decentralization is defined as the share of subnational expenditures over total government expenditures, and it is used to represent the extent of the fiscal devolution to the subnational governments. ${ }^{25}$ The dependency on transfers is defined as the share of intergovernmental transfers in total subnational revenues. As explained, intergovernmental transfers reduce the need for collecting own revenues and, therefore, might reduce tax effort and the collections of the property tax. Finally, government size is used to account for the relative magnitude and relevancy of the public sector and its components, including transfer programs, in the overall economy.

The level of development is represented by the per capita GDP. This variable provides information, among other things, on the levels of accumulated physical and human capital. For example, local governments in richer countries might have access to highly skilled personnel and more sophisticated equipment, so that their ability to administer and collect taxes is greater than that of less-developed countries. However, different levels of development can also be related to diverse patterns of subnational governments' financing, and thus the sign of the influence on property tax collections remains uncertain.

Property tax collections also depend on the value of land and structures in a country, which accounts for the potential property tax base. We approximate this value, following Bahl and Wallace (2010), with estimations computed on the basis of national wealth data provided by the World Bank (2006) (see Appendix Table 7A.2). We also control for the share of the urban population, because the size and composition of the tax base as well as the amount of property tax collections can be expected to be quite different in rural and urban areas. In addition, we include two dummy variables to control for the specific characteristics of Chile, where the administration and the authority over the property tax remain fully 
centralized, and of Ecuador and Mexico, the only countries in the sample where the cadastre is developed by the subnational governments (see Appendix Table 7A.1).

In practice, subnational governments can effectively enjoy additional fiscal autonomy only if the decentralization process also enhances the political representation of the population. Indeed, the share of local government expenditure over total government expenditures does not say much about the ability of taxpayers to choose their representatives and express their preferences for public goods, which, in turn, determines the extent of effective accountability of government officials and the degree of responsiveness to taxpayers' preferences. In order to account for these factors we consider two variables: the competition for public positions and an index of democracy. The degree of competition for public positions, we argue, serves to limit the ability of local authorities to take advantage of their political power, and thus helps to increase accountability and to contain corruption. Complementarily, the index of democracy serves to represent the ability of taxpayers to truly express their preferences.

Table 7.5 presents the results of our empirical analysis. The first regression (1) uses a fixed effects model in order to control in the estimation for all unobserved specific-country characteristics. As we might expect, the coefficient of fiscal decentralization is positive and statistically significant at the 1 percent level. A greater devolution of expenditure responsibilities to subnational governments requires relatively more revenues, providing incentives for greater property tax collections. The coefficient for the dependency on transfers takes a negative sign, and thus is negatively related to property tax collections, and it is statistically significant at the 5 percent level. This result is important because it supports our conjecture that the predominance of transfers can have a negative effect on tax effort. In order to control for the relative magnitude of intergovernmental transfers we also include an interaction term between transfers and the size of the (general) government with respect to the GDP. The coefficient of this variable is positive and significant, suggesting that the negative effect of transfers of property tax collections is reduced as the size of the government increases. A bigger public sector might need to count on other (than property) tax sources, and might also be better able to improve tax administration at every level and to implement 'non-distorting' or 'incentiveneutral' transfer programs. On average, the net effect of transfers on property tax collections becomes positive when the size of the public sector corresponds to 17.7 percent of the economy (displayed at the bottom of Table 7.5).

The level of development, represented by the GDP per capita, has a negative effect on property tax collections, which is significant at the 1 percent 
Table 7.5 Determinants of property tax collections (dependent variable: property tax collections (PTC) as a share of $G D P$ )

\begin{tabular}{|c|c|c|c|c|}
\hline : & $\begin{array}{l}\text { Fixed effects } \\
\text { (1) }\end{array}$ & $\begin{array}{l}\text { Random effects } \\
\text { (2) }\end{array}$ & $\begin{array}{l}\text { Random effects } \\
\text { (3) }\end{array}$ & $\begin{array}{c}\text { Random effects IV } \\
\text { (4) }\end{array}$ \\
\hline Fiscal decentralization ( $\%)$ & $\begin{array}{l}0.00919^{* * *} \\
(0.00242)\end{array}$ & $\begin{array}{l}0.01617^{* * *} \\
(0.00150)\end{array}$ & $\begin{array}{l}0.01445^{* * *} \\
(0.00135)\end{array}$ & $\begin{array}{l}0.03038^{* * *} \\
(0.00637)\end{array}$ \\
\hline Dependency on transfers (\%) & $\begin{array}{l}-0.01047^{* *} \\
(0.00509)\end{array}$ & $\begin{array}{l}-0.01053^{* * *} \\
(0.00234)\end{array}$ & $\begin{array}{l}-0.00502^{* *} \\
(0.00255)\end{array}$ & $\begin{array}{l}-0.02031^{* * *} \\
(0.00697)\end{array}$ \\
\hline $\begin{array}{l}\text { Interaction term (dep. on transfers } \times \\
\text { government size) }\end{array}$ & $\begin{array}{l}0.00059^{* *} \\
(0.00028)\end{array}$ & $\begin{array}{l}0.00072^{* * * *} \\
(0.00014)\end{array}$ & $\begin{array}{l}0.00043^{* * *} \\
(0.00015)\end{array}$ & $\begin{array}{l}0.00086^{* * *} \\
(0.00029)\end{array}$ \\
\hline Government size ( $\%$ GDP) & $\begin{array}{l}-0.01288 \\
(0.01554)\end{array}$ & $\begin{array}{l}-0.02731^{* * * *} \\
(0.00901)\end{array}$ & $\begin{array}{l}-0.00776 \\
(0.00952)\end{array}$ & $\begin{array}{l}-0.04679 * * \\
(0.01991)\end{array}$ \\
\hline Log of per capita GDP & $\begin{array}{l}-0.17295^{* * *} \\
(0.04730)\end{array}$ & $\begin{array}{l}-0.28330^{* * *} \\
(0.05883)\end{array}$ & $\begin{array}{l}-2.65021^{* * *} \\
(0.84908)\end{array}$ & $\begin{array}{l}-0.10259 \\
(0.11616)\end{array}$ \\
\hline Log of per capita GDP squared & & & $\begin{array}{l}0.12901^{* * *} \\
(0.04562)\end{array}$ & \\
\hline $\begin{array}{l}\text { Log of estimated property tax base } \\
\text { (as computed in Appendix Table 7A.2) }\end{array}$ & & $\begin{array}{l}0.27237^{* * *} \\
(0.02755)\end{array}$ & $\begin{array}{l}0.26629^{* * *} \\
(0.02683)\end{array}$ & $\begin{array}{l}0.40590^{* * *} \\
(0.08117)\end{array}$ \\
\hline Urban population $(\%)$ & $\begin{array}{c}0.00438 \\
(0.00743)\end{array}$ & $\begin{array}{l}-0.01564^{* * *} \\
(0.00280)\end{array}$ & $\begin{array}{l}-0.01050^{* * *} \\
(0.00326)\end{array}$ & $\begin{array}{l}-0.04710^{* * *} \\
(0.01429)\end{array}$ \\
\hline Municipal cadastre (dummy) & & $\begin{array}{l}-0.35632^{* * *} \\
(0.02223)\end{array}$ & $\begin{array}{l}-0.36153^{* * *} \\
(0.02096)\end{array}$ & $\begin{array}{l}-0.33473^{* * *} \\
(0.05178)\end{array}$ \\
\hline Chile (dummy) & & $\begin{array}{l}0.85010^{* * *} \\
(0.05660)\end{array}$ & $\begin{array}{l}0.83174^{* * *} \\
(0.05267)\end{array}$ & $\begin{array}{l}1.17456^{* * * *} \\
(0.16223)\end{array}$ \\
\hline Competition for public positions & $\begin{array}{l}0.09501^{* * *} \\
(0.02422)\end{array}$ & $\begin{array}{l}0.12712^{* * *} \\
(0.02600)\end{array}$ & $\begin{array}{l}0.12667^{* * *} \\
(0.02439)\end{array}$ & $\begin{array}{l}0.14642^{* * *} \\
(0.04218)\end{array}$ \\
\hline
\end{tabular}


Table 7.5 (continued)

\begin{tabular}{|c|c|c|c|c|}
\hline & $\begin{array}{l}\text { Fixed effects } \\
\text { (1) }\end{array}$ & $\begin{array}{l}\text { Random effects } \\
\text { (2) }\end{array}$ & $\begin{array}{l}\text { Random effects } \\
\text { (3) }\end{array}$ & $\begin{array}{c}\text { Random effects IV }{ }^{\mathrm{a}} \\
\text { (4) }\end{array}$ \\
\hline $\begin{array}{l}\text { Index of democracy } \\
\text { Constant }\end{array}$ & $\begin{array}{l}-0.03259^{* * *} \\
(0.00727) \\
1.68607^{* * *} \\
(0.63587)\end{array}$ & $\begin{array}{l}-0.05281^{* * *} \\
(0.00804) \\
3.53144^{* * * *} \\
(0.45747)\end{array}$ & $\begin{array}{l}-0.05330^{* * *} \\
(0.00702) \\
13.66880^{* * *} \\
(3.72743)\end{array}$ & $\begin{array}{l}-0.08504^{* * * *} \\
(0.01904) \\
4.51384^{* * * *} \\
(0.74078)\end{array}$ \\
\hline Observations & 115 & 115 & 115 & 115 \\
\hline Number of countries & 9 & 9 & 9 & 9 \\
\hline$R$-squared within & 0.5913 & 0.4667 & 0.4487 & 0.1603 \\
\hline$R$-squared between & 0.1392 & 0.9795 & 0.9921 & 0.9252 \\
\hline$R$-squared overall & 0.1288 & 0.9332 & 0.9396 & 0.8367 \\
\hline $\begin{array}{l}\text { Test of overidentifying restrictions } \\
p \text {-value }\end{array}$ & & & & $\begin{array}{l}0.233 \\
0.6294\end{array}$ \\
\hline $\begin{array}{l}\text { The mg. effect of GDP on PTC turns positive } \\
\text { when GDP per capita is: }\end{array}$ & & & 28,892 & \\
\hline $\begin{array}{l}\text { The mg. effect of transfers on PTC turns } \\
\text { positive when government size is: }\end{array}$ & 17.7 & 14.6 & 11.7 & 23.6 \\
\hline
\end{tabular}

Notes:

Robust standard errors in parentheses.

All regressions include time period dummies (not shown)

* significant at $10 \% ; * *$ significant at $5 \% ; * * *$ significant at $1 \%$

${ }^{a}$ The instrumented variables are fiscal decentralization, dependency on transfers, and the interaction term between the later and government size.

The instruments are log of population, political competition, openness to international trade and the price level of government expenditures. 
level. This result might appear as counterintuitive, because a greater level of development is usually associated not only with improved tax bases and administrative and tax collection capacity, but also with greater ability (and maybe willingness) to pay property taxes. An alternative explanation of this result would go along the same lines discussed above for the case of Brazil; higher GDP per capita may signal the availability of other tax sources of some significance and therefore a relative decrease in the reliance on property taxes as a source of local revenue. A simple analysis of the subnational tax mix and GDP per capita would seem to point in that direction; Figure 7.1(a) plots property tax collections as a share of subnational taxes against GDP per capita. There appears to be a clear negative relationship between these variables, suggesting that the relative importance of the property in subnational governments' financing decreases as the country GDP per capita increases. ${ }^{26}$

Finally, among the other controls only competition for public positions and the index of democracy are statistically significant. As expected, the variable used to represent accountability and the limits to corruption - competition for public positions, is positively related to property tax collections. In contrast, the coefficient of the index of democracy has a negative sign, suggesting that the property tax might not enjoy political acceptability. ${ }^{27}$

The second column of Table 7.5 presents the results of a random effects model in which we are able to include time-constant variables, at the same time partially controlling for country-specific effects. The results under this specification are fairly consistent with the findings under fixed effects, but all controls are now significant at the 1 percent level. In particular, government size and the percentage of urban population appear to be negatively correlated with property tax collections.

The time-invariant variables that are included in this estimation are (the logarithm of) the estimated size of the potential tax base, a dummy that takes the value of one for Chile, and a dummy that assigns a value of one to the two countries of the sample in which the cadastre is developed locally, Ecuador and Mexico. The signs of the coefficients of the timeconstant variables are in line with our expectations. The greater the size of the potential tax base the greater the relative amount of property tax collections ${ }^{28}$ On the other hand, Ecuador and Mexico appear as collecting fewer taxes due to the reliance on, presumably ill-equipped, subnational tax administration; Chile performs better than the average of the sample due to the opposite reason.

Regression (3) in Table 7.5 introduces the square of the GDP per capita in order to allow for a non-linear influence on property tax collections. The general results do not significantly differ from the previous regression, 
a) Share of property taxes over subnational tax collections and GDP per capita

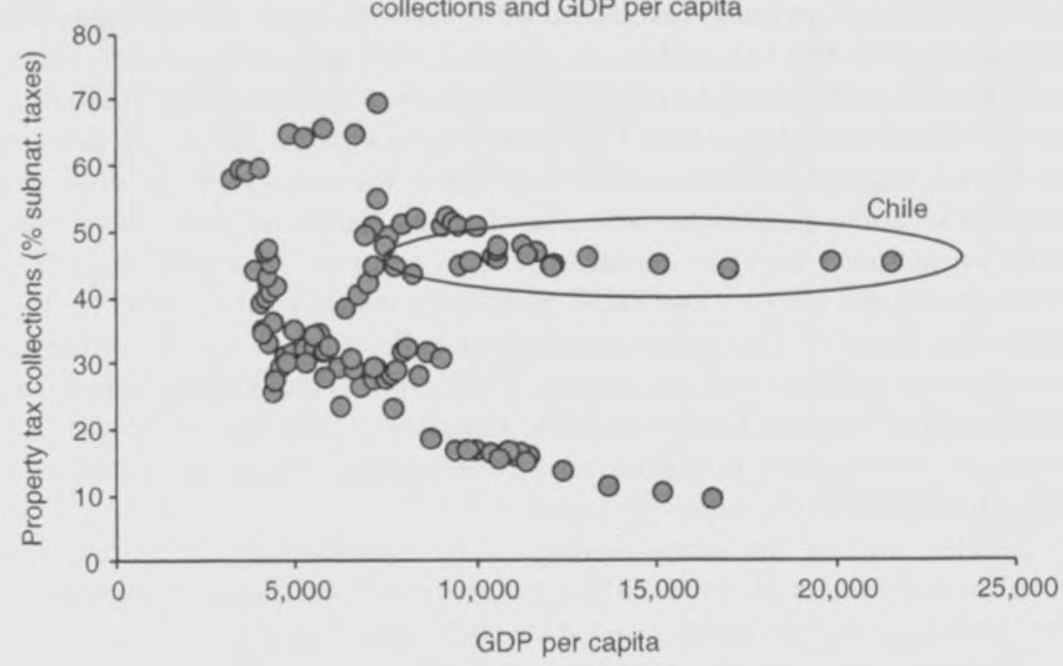

b) Property tax collections and corruption

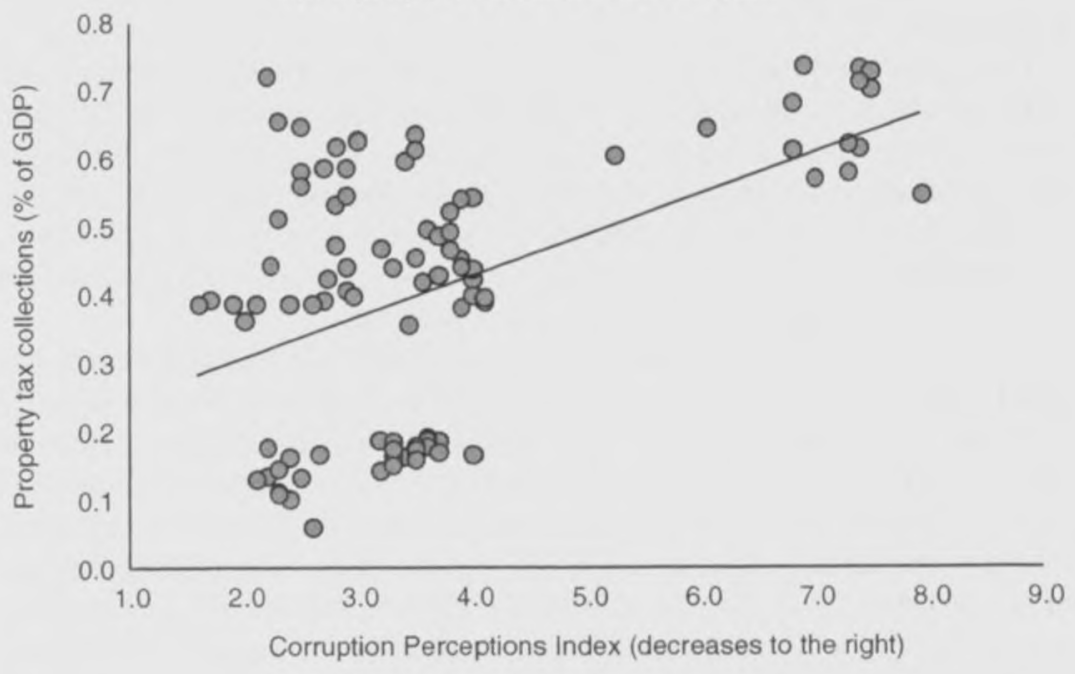

Sources: (a) ECLAC (property taxes and subnational tax collections) and Penn World Table (GDP per capita); (b) ECLAC (property taxes) and Transparency International (Corruption Perceptions Index).

Figure 7.1 Relationship of property tax collections with GDP per capita and corruption 
and the square of the GDP per capita is positive and statistically significant at the 1 percent level; implying that the negative marginal effect of development on property tax collection decreases with per capita GDP. ${ }^{29}$

A relevant concern about the econometric specification is the existence of an endogenous relationship between some of the explanatory variables and property tax collections. In particular we may expect a certain degree of reverse causality; that is, we can expect the extent of fiscal decentralization and the amount of transfers to be influenced by the level of property tax collections. In order to address this problem, in regression (4) we use a generalized two-stage least squares (G2SLS) random effects model, where we introduce instrumental variables (IV) to correct possible biases in the estimators. The instrumented variables are fiscal decentralization, dependency on transfers, and the interaction term between dependency on transfers and the size of government. As instruments we choose the $\log$ of population, the degree of political (party) competition, openness to international trade and the price level of government expenditures. ${ }^{30}$ The set of instruments is highly correlated with the three endogenous variables but uncorrelated with property tax collections. Moreover, the test of overidentifying restrictions (in the table) fails to reject the null that the set of excluded variables are valid instruments. ${ }^{31}$ In general, although the magnitude of the coefficients exhibit relevant corrections, their signs and statistical significance remain roughly unaffected. ${ }^{32}$

Summarizing, property tax revenue performance improves with the extent of fiscal decentralization, the presence of accountability mechanisms, and the size of the potential tax base. In contrast, tax collections decrease with the index of democracy, higher dependency on transfers, and the fact that the cadastre is administered locally.

Finally, a variable that we have considered as a potentially important determinant of property tax collections is the perception of corruption, which even if available, has been excluded from the econometric analysis due to the small number of observations. Figure 7.1(b) presents a scatter plot where we verify an apparent correlation between property tax collections as a share of GDP and the Corruption Perceptions Index. The Corruption Perceptions Index assigns a greater value to those countries that are less corrupt, thus the positively sloped trend line suggests that less corrupt countries are, on average, able to collect more property taxes, ${ }^{33}$

This analysis provides important insights about the determinants of property tax collections in Latin America. In principle, given that we do not have information about what the 'correct' level of property tax collections is, we cannot say a priori whether increasing tax collections is a desirable thing. However, it is well known that Latin American countries perform below international standards, and since we have no 
reason to presume that their subnational expenditure needs are particularly low, then we can conclude that certain factors have an excessively (undesirable) negative influence on property tax collections. The dependency on transfers and local responsibility for the implementation of the cadastre are two relevant factors in reducing property tax collections and over which the authorities might have some degree of control. For instance, the design of the fiscal decentralization might incorporate new subnational own-revenue sources, such that the local authorities and their constituencies internalize the value of revenue autonomy and start exercising higher tax effort in order to finance expanded local services. Nevertheless, greater autonomy at the local level does not mean that complex, long-lasting and expensive tasks such as building a complete cadastre of properties can be undertaken without assistance from the central government. The movement towards greater revenue collections and autonomy, especially in developing countries, must be gradual, with a central government that is able to support and assist local administrations in their transition to more decentralized and efficient arrangements.

\section{CONCLUSIONS AND POLICY RECOMMENDATIONS}

Successful decentralization in terms of efficiency and fiscal responsibility depends critically on the provision of adequate revenue autonomy to subnational governments. The property tax is widely considered as the most appropriate instrument to promote tax autonomy at the local level, while other taxes such as vehicle taxes, local excise, piggyback personal income taxes, or business permit taxes should also play an important role in the promotion of local tax autonomy. However, it is difficult to argue strongly for greater property tax autonomy when many local governments in Latin America appear not to be taking advantage of the autonomy that is currently granted in the laws. An important piece of any potential indictment is that, judging from what is collected in other regions of the world, actual property tax collections in the region are a small fraction of what appears to be the revenue potential. In this context, any attempts to achieve more efficient forms of decentralization in the Latin American region via increased revenue autonomy for local governments would need to grapple with the question of how to achieve significant improvement in local property tax collections.

Property tax collections are determined by a wide array of factors. These factors include, among others, the extent or depth of fiscal decentralization 
reforms, the structure of subnational financing, the level of development, the potential size of the property tax base, and basic institutional characteristics of the public sector. In particular, we find that the predominance of intergovernmental transfers in the subnational finance systems have a negative effect on property tax collections and that, for the most part, subnational governments are unwilling or do not seem capable of taking advantage of the devolution of this revenue source. In this context, getting the property tax to perform correctly may take more than just addressing the issues, complex on their own, of designing, administering and enforcing the property tax itself. For instance, we argue that government responsiveness towards taxpayers' needs and improvements in cultural factors such as tax morale might be necessary to increase property tax collections.

Effective devolution of the property tax to subnational governments should be accompanied by certain preconditions. Some of these preconditions are not currently met by some Latin American countries, and thus provide a good starting point to draw meaningful policy recommendations to guide future reforms. Of course, country circumstances and conditions differ, so not all recommendations should be expected to apply to each case.

There is a clear need for most local governments to develop their administrative and technical capacities. This rather obvious recommendation has long been recognized in the literature, but it remains as an unavoidable and pending task. Two possible strategies to move forward in this regard are the implementation of asymmetric property tax assignments and the provision of technical and financial assistance to those local governments with lower administrative capacity. Moreover, improving the performance of the property tax in the region would also benefit from strengthening institutions and reshaping cultural attitudes. In particular, it is necessary to make local authorities understand the importance of own-tax revenues and to show taxpayers the connection between property tax payments and local services. This will not be an easy task, but successful experiences such as those provided by the cities of Bogota and Lima might serve as relevant examples (see Martinez-Vazquez, 2010). Finally, some reforms to the intergovernmental finance system may be necessary. It is particularly important to correct the incentives provided by the system of transfers. In this chapter we provide some evidence of a potential negative effect of intergovernmental transfers on property tax collections. These issues still need to be carefully investigated.

Overall, and somewhat paradoxically, greater revenue autonomy for Latin American local governments in the form of a more effective use of the property tax might depend in some cases on a deeper involvement of the central government in the administration, collection and enforcement 
of the property tax. Making property taxes work more effectively will continue to be a complex challenge and no simple 'silver bullet' simple solutions are in sight. Attention must be given to 'internal' factors, including issues of administration and local capacity, but equal attention must also be given to an array of factors that are 'external' to the property tax collection process itself.

\section{NOTES}

* We are thankful to ECLAC for financial support and Juan Pablo Jiménez and Gustavo Canavire-Bacarreza for helpful comments. We are also thankful to Andrea Podestá for useful research assistance.

1. The taxation of property comes in many different modalities and within each one of them different approaches have been used in the international practice, all of which offer different advantages and disadvantages. Many of these are reviewed in Bird and Slack (2004) and Bahl et al. (2008a, 2010).

2. For a detailed description of property tax systems in Latin America, see De Cesare and Lazo Marin (2008).

3. The advantages of the property tax as a local tax are reviewed, among many others, in Oates (1999), Bird (2006), and Bahl et al. (2008b).

4. The concept of equity in the distribution of income ultimately deals with who bears the burden of the tax, or the incidence of the tax. Zodrow (2007) provides a brief review of the property tax incidence literature.

5. Based on an empirical analysis encompassing 34 developing countries and 22 developed countries, Sepulveda and Martinez-Vazquez (2011) suggest that the local governments might actually contribute to improving the distribution of income. However, this conclusion is subject to a public sector playing a significant role in the economy (more than $20 \%$ of the GDP), a condition that is not observed in Latin American countries, where total expenditures of the general government represent, on average during 2007, less than $15 \%$ of the GDP (Penn World Table, Heston et al., 2009).

6. Discussions about the property tax and the characteristics of a good local tax are discussed, for instance, in McLure (1994), McCluskey and Williams (1999), McCluskey and Plimmer (2007), Bahl and Bird (2008) and Martinez-Vazquez et al. (2010).

7. Brennan and Buchanan (1980) suggest that tax competition has a corrective effect on the overall amount of public expenditures, because it limits the natural tendency of governments to spend more than the efficient amount.

8. Oates (2006) provides a more recent discussion about the decentralization theorem and the channels through which fiscal decentralization can lead to net welfare gains for society.

9. See Shah (2004) for a discussion about the possible factors explaining the widespread decentralization movement among developing and transition countries.

10. In the equality provided by Bahl and Martinez-Vazquez (2008) both sides of the identity are divided by the GDP. By doing this, the tax collections are expressed in relative terms, thus the figures for different countries are comparable and the analysis can be carried out on a cross-sectional basis. This equality was previously presented, for instance, in Bahl (1979).

11. If the collection ratio is assumed to be set at 1 by the tax authorities, then this term might still have a value different from one, which could be interpreted as a deviation of the 'true' market value of taxable properties due to an inaccurate assessment of the value of taxable properties. In this framework, however, we assume that the 
market value is correctly measured and that the collection ratio serves only as a policy instrument.

12. The literature reserves the term 'tax avoidance' to refer to any legal form of noncompliance. Tax avoidance corresponds to the taxpayers' initiatives to minimize their tax burden by taking advantage of preferential treatments and exemptions contemplated in the law. In this model, tax avoidance is accounted for as a reduction of taxable market value of properties, and thus a reduction of the property tax base.

13. The basic structure of the traditional tax evasion model is developed by Allingham and Sandmo (1972) and Srinivasan (1973), and the cost of enforcement is incorporated by Slemrod and Yitzhaki (1987). Two surveys on the theory of tax compliance are provided by Andreoni et al. (1998) and Sandmo (2005).

14. A comprehensive review of the concept of tax morale and the relevant literature is provided by Torgler (2007).

15. See, for instance, Fisman and Gatti (2002) for an empirical analysis providing strong support to the hypothesis that fiscal decentralization reduces corruption.

16. $\bar{l}^{\prime}$ can be computed as the total amount of taxes actually collected among all government units divided by the overall tax base. This definition corresponds to the weighted average of the effective tax rate for all government units. A different alternative, not less convenient, consists in computing the benchmark as the simple average of the effective tax rates for the available sample (of countries or subnational governments). The weighted average will be expected to be greater (smaller) than the simple average as long as per capita collections tend to increase (decrease) with the jurisdiction size.

17. Other sources of own-revenue collections (for example, fees and financial debt) are excluded, without loss of generality, in order to simplify the analysis. Here we also disregard whether the intergovernmental transfers are earmarked or not, but this does not alter the fact that any degree of discretion over own-revenue collections translates into discretion 'in the margin' over the total amount of government expenditures.

18. As a corollary of this result we could say that if intergovernmental transfers increase, do not change, or decrease tax effort in a jurisdiction, then the demand for public goods within that jurisdiction has been revealed to be elastic, have unitary elasticity, or be inelastic.

19. Equation (7.8) corresponds to a strictly budgetary identity, but it can be modified in order to model the supply and demand for subnational public goods and services. The left-hand side would have to incorporate a production function describing the amount and quality of public goods and services, and in the right-hand side the tax collections would represent the willingness to pay for these outputs.

20. For a review and an extensive discussion about the alternative methodologies available to measure fiscal capacity see, for instance, US ACIR (1986) and Boex and MartinezVazquez (2007).

21. One might argue that foreign tax policies also affect tax collections because they can induce the taxpayers to emigrate in order to capitalize on tax advantages. This is especially relevant in cases where taxpayers are very mobile, as in corporations. In any case, mobility is fully accounted for in this equation by a decrease in the size of the tax base. Another way in which foreign tax policies may also affect tax collections is through spatial tax competition across countries. In this case tax rates and other policies set in foreign countries can affect the tax policy choice in any one country.

22. The choice of these countries responds to data availability. Both Brazil and Peru provide public information about subnational finances and basic demographic and development indicators. The main data sources are the National Treasury of Brazil and the Ministry of Economy and Finance of Peru.

23. A similar result is found in the analysis of property tax collections at the international level, which is presented later in this section, and where we discuss possible interpretations in more detail.

24. The description and sources of the variables used in the analysis, as well as the summary statistics, are presented in Appendix Tables 7A.3 and 7A.4, respectively. 
25. Even though this variable does not capture the effective autonomy of subnational government, lacking any better option we follow the most common practice in the decentralization literature and use this variable to proxy for the level of fiscal decentralization.

26. The data for Chile, within the oval in Figure 7.1(a), exhibit a distinctive pattern, which has been accounted for by the country dummy in the econometric specification.

27. In order to account for additional country-specific characteristics we also considered regional disparities in GDP per capita as an additional control variable. The correlation between this variable and property tax collections as a share of GDP is -0.686 , suggesting that countries with greater regional disparities tend to collect fewer property taxes. However, we do not present the results for this variable because its inclusion in the estimating equations drastically reduces the number of observations.

28. The explicit consideration of the potential tax base might also help to explain the negative sign of the urban population's coefficient. Once the size of the tax base has been accounted for, a negative relationship between urban population and property tax collections might suggest that urban areas have a greater concentration of unregistered properties and exempted taxpayers than is the case in rural areas.

29. The average effect of development on property tax collections turns out to be positive when the GDP per capita is US\$28,892. That point, however, is irrelevant because no country in the sample reaches that value.

30. See Appendix Tables 7A.3 and 7A.4 for a description of the variables used and summary statistics.

31. The test of overidentifying restrictions was developed for Stata by Schaffer and Stillman (2006).

32. The only exception is the level of development, which turns out to be statistically insignificant. We cannot know, however, if this change is due to the correction of a bias or due to possible collinearity introduced by the instrumentation for the endogenous variables.

33. The Corruption Perceptions Index is prepared by Transparency International, and the data can be retrieved from http://www.transparency.org/policy_research/ surveys_indices/cpi.

\section{REFERENCES}

Ahmad, Ehtisham and Giorgio Brosio (2008), 'Political economy of multi-level tax assignments in Latin American countries: earmarked revenue versus tax autonomy', International Monetary Fund Working Paper No. 71, Washington, DC.

Allingham, Michael and Agnar Sandmo (1972), 'Income tax evasion: a theoretical analysis', Journal of Public Economics, 1: 323-38.

Alm, James and Jorge Martinez-Vazquez (2007), 'Tax morale and tax evasion in Latin America', International Studies Program Working Paper No. 4, Andrew Young School of Policy Studies, Georgia State University, Atlanta, GA.

Andreoni, James, Brian Erard and Jonathan Feinstein (1998), 'Tax compliance', Journal of Economic Literature, 36 (2): 818-60.

Bahl, Roy (1979), 'The practice of urban property taxation in less developed countries', in Bahl (ed.), The Taxation of Urban Property in Less Developed Countries, Madison, WI: University of Wisconsin Press pp. 947.

Bahl, Roy and Richard Bird (2008), 'Subnational taxes in developing countries: the way forward', Public Budgeting \& Finance, 28 (4): 1-25.

Bahl, Roy and Jorge Martinez-Vazquez (2008), 'The determinants of revenue performance', in Bahl et al. (eds) (2008a), pp. 35-57. 
Bahl, Roy, Jorge Martinez-Vazquez and Joan Youngman (eds) (2008a), Making the Property Tax Work: Experiences in Developing and Transitional Countries, Cambridge, MA: Lincoln Institute of Land Policies.

Bahl, Roy, Jorge Martinez-Vazquez and Joan Youngman (2008b), 'The property tax in practice', in Bahl et al. (eds) (2008a), pp. 3-16.

Bahl, Roy, Jorge Martinez-Vazquez and Joan Youngman (eds) (2010), Challenging the Conventional Wisdom on the Property Tax, Cambridge, MA: Lincoln Institute of Land Policies.

Bahl, Roy and Sally Wallace (2010), 'A new paradigm for property taxation in developing countries', in Bahl et al. (eds), pp. 165-201.

Bird, Richard (2006), 'Local and regional revenues: realities and prospects', in R. Bird and F. Vaillancourt (eds), Perspectives on Fiscal Federalism, Washington, DC: World Bank, pp. 165-201.

Bird, Richard, Jorge Martinez-Vazquez and Benno Torgler (2006), 'Societal institutions and tax effort in developing countries', in J. Alm, J. Martinez-Vazquez and M. Rider (eds), The Challenges of Tax Reform in a Global Economy, New York: Springer, pp. 283-338.

Bird, Richard, Jorge Martinez-Vazquez and Benno Torgler (2008), 'Tax effort in developing countries and high income countries: the impact of corruption, voice and accountability', Economic Analysis \& Policy, 38 (1): 55-71.

Bird, Richard and Enid Slack (eds) (2004), International Handbook of Land Property Taxation, Cheltenham, UK and Northampton, MA, USA: Edward Elgar.

Boex, Jamie and Jorge Martinez-Vazquez (2007), 'Designing intergovernmental equalization transfers with imperfect data: concepts, practices, and lessons', in J. Martinez-Vazquez and R. Searle (eds), The Design of Equalization Transfers, Amsterdam: Elsevier, pp. 291-343.

Brennan, Geoffrey and James Buchanan (1980), The Power to Tax: Analytical Foundations of a Fiscal Constitution, Cambridge: Cambridge University Press.

De Cesare, Claudia (2002), 'Toward more effective property tax systems in Latin America', Lincoln Institute of Land Policy, Land Lines, 14 (1): 9-11.

De Cesare, Claudia and José Francisco Lazo Marín (2008), 'Impuestos a los Patrimonios en América Latina', Serie Macroeconomia del Desarrollo No. 66, Comisión Económica para América Latina y el Caribe (CEPAL), Naciones Unidas.

Fisman, Raymond and Roberta Gatti (2002), 'Decentralization and corruption: evidence across countries', Journal of Public Economics, 83 (3): 325 - 45.

Heston, Alan, Robert Summers and Bettina Aten (2009), Penn World Table Version 6.3, Center for International Comparisons of Production, Income and Prices, University of Pennsylvania, Philadelphia, PA.

Kunte, A., K. Hamilton, J. Dixon and M. Clemens (1998), 'Estimating national wealth: methodology and results', Environment Department Paper 57, World Bank, Washington, DC.

Lopez, J. Humberto and Guillermo Perry (2008), 'Inequality in Latin America: determinants and consequences', Policy Research Working Paper 4504, World Bank, Washington, DC.

Martinez-Vazquez, Jorge (2010), 'Municipal finance in Latin America', International Studies Program Working Paper, Andrew Young School of Policy Studies, Georgia State University, Atlanta, GA.

Martinez-Vazquez, Jorge, Luc Noiset and Mark Rider (2010), 'Assignment of the 
property tax: should developing countries follow the conventional wisdom?', in Bahl et al. (eds), pp. 299-349.

McCluskey, William and Frances Plimmer (2007), 'The potential for the property tax in the 2004 accession countries of Central and Eastern Europe', RICS Foundation Research Paper Series, London, Vol. 7, No. 17.

McCluskey, William and Brendan Williams (1999), 'Introduction: a comparative evaluation', in W. McCluskey (ed.), Property Taxation: An International Comparative Review, Aldershot, UK and Brookfield, VT: Ashgate, pp. 1-31.

McLure, Charles (1994), 'The tax assignment problem: ends, means, and constraints', Australian Tax Forum, 11: 153-83.

Musgrave, Richard (1959), The Theory of Public Finance, New York: McGraw-Hill.

Oates, Wallace (1972), Fiscal Federalism, New York: Harcourt Brace Jovanovich.

Oates, Wallace (1999), 'Local property taxation: an assessment', Lincoln Institute of Land Policy, Land Lines, 11 (3): 1-3.

Oates, Wallace (2006), 'On the theory and practice of fiscal decentralization', Institute for Federalism and Intergovernmental Relations (IFIR) Working Paper 05, University of Kentucky, Lexington, KY.

Sandmo, Agnar (2005), 'The theory of tax evasion: a retrospective view', National Tax Journal, 58 (4): 643-63.

Schaffer, Mark and Steven Stillman (2006), 'xtoverid: Stata module to calculate tests of overidentifying restrictions after xtreg, xtivreg, xtivreg2 and xthtaylor', available at: http://ideas.repec.org/c/boc/bocode/s456779.html (accessed May 10, 2010).

Sepulveda, Cristian and Jorge Martinez-Vazquez (2011), 'The consequences of fiscal decentralization on poverty and income inequality', Environment and Planning C: Government and Policy, 29 (2), 321-43.

Shah, Anwar (2004), 'Fiscal decentralization in developing and transitional economies: progress, problems and promise', Policy Research Working Paper 3282, World Bank, Washington, DC.

Slemrod, Joel and Shlomo Yitzhaki (1987), 'The optimal size of a tax collection agency', Scandinavian Journal of Economics, 89 (2): 183-92.

Srinivasan, T.N. (1973), 'Tax evasion: a model', Journal of Public Economics, 2: 339- 46.

Tiebout, Charles (1956), 'A pure theory of local expenditures', Journal of Political Economy, 64 (5): 416-24.

Torgler, Benno (2005a), 'Tax morale and direct democracy', European Journal of Political Economy, 21 (2): 525-31.

Torgler, Benno (2005b), 'Tax morale in Latin America', Public Choice, 122: 133-57.

Torgler, Benno (2007), Tax Compliance and Tax Morale: A Theoretical and Empirical Analysis, Cheltenham, UK and Northampton, MA, USA: Edward Elgar.

Torgler, Benno, Ihsan C. Demir, Alison Macintyre and Markus Schaffner (2008), 'Causes and consequences of tax morale: an empirical investigation', Economic Analysis \& Policy, 38 (2): 313-39.

United States Advisory Commission on Intergovernmental Relations (ACIR) (1986), 'Measuring State Fiscal Capacity: Alternative Methods and their Uses', Information Report M-150, ACIR, Washington, DC. 
World Bank (2006), Where Is the Wealth of Nations? Measuring Capital for the 21st Century, Washington, DC: World Bank.

Zodrow, George (2007), 'The property tax incidence debate and the mix of state and local finance of local public expenditures', CESifo Economic Studies, 53 (4): 495-521. 


\section{APPENDIX 7A}

Table 7.A.1 Main characteristics of property tax systems in Latin America

\begin{tabular}{|c|c|c|c|c|c|c|}
\hline \multirow[t]{2}{*}{ Country } & \multirow{2}{*}{$\begin{array}{l}\text { Revenue } \\
\text { assignment }\end{array}$} & \multirow{2}{*}{$\begin{array}{l}\text { Authority to change } \\
\text { the tax structure }\end{array}$} & \multicolumn{4}{|c|}{ Administration } \\
\hline & & & Cadastre & $\begin{array}{l}\text { Billing and } \\
\text { collection }\end{array}$ & Appeals & Assessment \\
\hline Argentina & $\begin{array}{l}\text { Provincial and } \\
\text { local govts }\end{array}$ & $\begin{array}{l}\text { Provincial and local } \\
\text { governments }\end{array}$ & Cadastral office & $\begin{array}{l}\text { Provincial } \\
\text { and local } \\
\text { governments }\end{array}$ & $\begin{array}{l}\text { Formal appeal } \\
\text { processes } \\
\text { at both } \\
\text { government } \\
\text { levels }\end{array}$ & Market value \\
\hline Bolivia & $\begin{array}{l}\text { Municipal } \\
\text { governments }\end{array}$ & $\begin{array}{l}\text { Central govt } \\
\text { (Ministerio de } \\
\text { Finanzas) along with } \\
\text { municipal governments }\end{array}$ & $\begin{array}{l}\text { Dirección Nacional de } \\
\text { Catastro Urbano }\end{array}$ & $\begin{array}{l}\text { Municipal } \\
\text { governments }\end{array}$ & & Market value \\
\hline Brazil & $\begin{array}{l}\text { Central (rural) } \\
\text { and municipal } \\
\text { (urban) govts }\end{array}$ & $\begin{array}{l}\text { Central and municipal } \\
\text { governments }\end{array}$ & $\begin{array}{l}\text { Central (rural) and } \\
\text { municipal (urban) govts }\end{array}$ & $\begin{array}{l}\text { Municipal } \\
\text { governments }\end{array}$ & & Market value \\
\hline Chile & $\begin{array}{l}\text { Municipal } \\
\text { governments }\end{array}$ & Central government & $\begin{array}{l}\text { Servicios de Impuestos } \\
\text { Internos (SII) }\end{array}$ & $\begin{array}{l}\text { Central } \\
\text { government } \\
\text { (Treasury) }\end{array}$ & $\begin{array}{l}\text { Internal Tax } \\
\text { Service, Special } \\
\text { Appeals Court } \\
\text { on Property } \\
\text { Valuation, } \\
\text { Supreme Court }\end{array}$ & $\begin{array}{l}\text { Area by } \\
\text { location } \\
\text { for land, } \\
\text { construction } \\
\text { value for } \\
\text { buildings }\end{array}$ \\
\hline
\end{tabular}




\begin{tabular}{|c|c|c|c|c|c|c|}
\hline Colombia & $\begin{array}{l}\text { Municipal } \\
\text { governments }\end{array}$ & $\begin{array}{l}\text { National Congress } \\
\text { defines tax base and } \\
\text { rate. A range of rates } \\
\text { is established within } \\
\text { which municips are } \\
\text { free to choose }\end{array}$ & $\begin{array}{l}\text { Instituto Geográfico } \\
\text { Agustín Codazzi } \\
\text { (IGAC) }\end{array}$ & $\begin{array}{l}\text { Municipal } \\
\text { governments } \\
\text { (Secretarias } \\
\text { de Hacienda) }\end{array}$ & $\begin{array}{l}\text { Cadastral } \\
\text { Division, } \\
\text { petition tax } \\
\text { administration }\end{array}$ & Market value \\
\hline Costa Rica & $\begin{array}{l}\text { Municipal } \\
\text { governments }\end{array}$ & & $\begin{array}{l}\text { Municipal governments } \\
\text { (Catastro Nacional) }\end{array}$ & $\begin{array}{l}\text { Municipal } \\
\text { governments }\end{array}$ & & Market value \\
\hline Ecuador & $\begin{array}{l}\text { Municipal } \\
\text { governments }\end{array}$ & $\begin{array}{l}\text { Central govt along } \\
\text { with municipalities' } \\
\text { ability to set rates }\end{array}$ & Municipal governments & $\begin{array}{l}\text { Municipal } \\
\text { governments }\end{array}$ & & Market value \\
\hline Guatemala & $\begin{array}{l}\text { Central and } \\
\text { municipal } \\
\text { governments }\end{array}$ & $\begin{array}{l}\text { Central and municipal } \\
\text { governments }\end{array}$ & $\begin{array}{l}\text { Central government } \\
\text { (Dirección General de } \\
\text { Catastro) }\end{array}$ & $\begin{array}{l}\text { Mainly } \\
\text { central govt, } \\
\text { except for } \\
\text { municipalities } \\
\text { with } \\
\text { technical and } \\
\text { administrative } \\
\text { capacity }\end{array}$ & & Market value \\
\hline Honduras & $\begin{array}{l}\text { Municipal } \\
\text { governments }\end{array}$ & $\begin{array}{l}\text { Municipal } \\
\text { governments }\end{array}$ & Municipal governments & $\begin{array}{l}\text { Municipal } \\
\text { governments }\end{array}$ & & $\begin{array}{l}\text { Market } \\
\text { value, use } \\
\text { of the land, } \\
\text { location and } \\
\text { improvements }\end{array}$ \\
\hline
\end{tabular}


Table 7A.I (continued)

\begin{tabular}{|c|c|c|c|c|c|c|}
\hline \multirow[t]{2}{*}{ Country } & \multirow{2}{*}{$\begin{array}{l}\text { Revenue } \\
\text { assignment }\end{array}$} & \multirow{2}{*}{$\begin{array}{l}\text { Authority to change } \\
\text { the tax structure }\end{array}$} & \multicolumn{4}{|c|}{ Administration } \\
\hline & & & Cadastre & $\begin{array}{l}\text { Billing and } \\
\text { collection }\end{array}$ & Appeals & Assessment \\
\hline Mexico & $\begin{array}{l}\text { Municipal } \\
\text { governments }\end{array}$ & $\begin{array}{l}\text { State and municipal } \\
\text { governments jointly }\end{array}$ & Municipal governments & $\begin{array}{l}\text { Local } \\
\text { governments } \\
\text { (local } \\
\text { Treasury } \\
\text { offices) }\end{array}$ & $\begin{array}{l}\text { Fiscal } \\
\text { authority } \\
\text { judicial branch }\end{array}$ & Market value \\
\hline Nicaragua & $\begin{array}{l}\text { Municipal } \\
\text { governments }\end{array}$ & $\begin{array}{l}\text { Central government } \\
\text { with municipalities' } \\
\text { ability to grant } \\
\text { additional exemptions }\end{array}$ & $\begin{array}{l}\text { Comisión Nacional de } \\
\text { Catastro }\end{array}$ & $\begin{array}{l}\text { Municipal } \\
\text { governments }\end{array}$ & & $\begin{array}{l}\text { Cadastral } \\
\text { value }\end{array}$ \\
\hline Panama & $\begin{array}{l}\text { Central } \\
\text { government }\end{array}$ & $\begin{array}{l}\text { Central and provincial } \\
\text { governments }\end{array}$ & Central government & $\begin{array}{l}\text { Provincial } \\
\text { governments }\end{array}$ & & \\
\hline Paraguay & $\begin{array}{l}\text { Municipal } \\
\text { governments } \\
\text { and } \\
\text { departments }\end{array}$ & $\begin{array}{l}\text { Central government } \\
\text { (Ministerio de } \\
\text { Finanzas Públicas) }\end{array}$ & $\begin{array}{l}\text { Mainly central govt, } \\
\text { except for those } \\
\text { municips with technical } \\
\text { and adm. capacity }\end{array}$ & $\begin{array}{l}\text { Municipal } \\
\text { governments }\end{array}$ & & Market value \\
\hline
\end{tabular}




\begin{tabular}{|c|c|c|c|c|c|}
\hline Peru & $\begin{array}{l}\text { Municipal } \\
\text { and district } \\
\text { governments }\end{array}$ & $\begin{array}{l}\text { Central, municipal and } \\
\text { district governments }\end{array}$ & $\begin{array}{l}\text { Central government } \\
\text { (Comisión Nacional de } \\
\text { Tasaciones: CONATA) }\end{array}$ & $\begin{array}{l}\text { Municipal } \\
\text { and district } \\
\text { governments }\end{array}$ & Market value \\
\hline $\begin{array}{l}\text { Dominican } \\
\text { Republic }\end{array}$ & $\begin{array}{l}\text { Central } \\
\text { government }\end{array}$ & Central government & $\begin{array}{l}\text { Central government } \\
\text { (Dirección General del } \\
\text { Catastro Nacional) }\end{array}$ & $\begin{array}{l}\text { Central } \\
\text { government }\end{array}$ & $\begin{array}{l}\text { Value } \\
\text { greater than } \\
\text { approximately } \\
\text { US\$150,000 }\end{array}$ \\
\hline Uruguay & Departments & $\begin{array}{l}\text { Central and municipal } \\
\text { government, along } \\
\text { with departments }\end{array}$ & $\begin{array}{l}\text { Central govt (rural; } \\
\text { Dirección Nacional } \\
\text { de Catastro) and } \\
\text { departments (urban) }\end{array}$ & Departments & $\begin{array}{l}\text { Market value } \\
\text { plus additional } \\
20 \% \text { for } \\
\text { improvements } \\
\text { the rural cases }\end{array}$ \\
\hline Venezuela & $\begin{array}{l}\text { Municipal } \\
\text { governments }\end{array}$ & $\begin{array}{l}\text { Municipal } \\
\text { governments }\end{array}$ & Municipal governments & $\begin{array}{l}\text { Municipal } \\
\text { governments }\end{array}$ & Market value \\
\hline
\end{tabular}

Source: Martinez-Vazquez et al. (2010). 
Table 7A.2 Estimates of potential property tax base by country and region, 2000 (in US\$ per capita)

\begin{tabular}{|c|c|c|c|c|c|c|}
\hline \multirow[t]{2}{*}{ Region } & \multirow[t]{2}{*}{ Country } & \multicolumn{3}{|c|}{ Potential rural tax base } & \multirow{2}{*}{$\begin{array}{c}\text { Potential } \\
\text { urban tax } \\
\text { base } \\
\text { Urban } \\
\text { land + } \\
\text { structures* }\end{array}$} & \multirow{2}{*}{$\begin{array}{l}\text { Potential } \\
\text { base of } \\
\text { the } \\
\text { property } \\
\text { tax }\end{array}$} \\
\hline & & Cropland & $\begin{array}{l}\text { Pasture- } \\
\text { land }\end{array}$ & $\begin{array}{c}\text { Cropland + } \\
\text { pasture- } \\
\text { land }\end{array}$ & & \\
\hline & Latin America & & & & & \\
\hline SA & Argentina & 3,632 & 2,754 & 6,386 & 18,301 & 24,687 \\
\hline $\mathrm{CA}$ & Belize & 5,201 & 133 & 5,334 & 9,298 & 14,632 \\
\hline SA & $\begin{array}{l}\text { Bolivia } \\
\text { (Plurinational } \\
\text { State of) }\end{array}$ & 1,550 & 541 & 2,091 & 2,021 & 4,112 \\
\hline SA & Brazil & 1,998 & 1,311 & 3,309 & 9,234 & 12,543 \\
\hline SA & Chile & 2,443 & 1,001 & 3,444 & 10,235 & 13,679 \\
\hline SA & Colombia & 1,911 & 978 & 2,889 & 4,665 & 7,554 \\
\hline $\mathrm{CA}$ & Costa Rica & 5,811 & 1,310 & 7,121 & 7,989 & 15,110 \\
\hline SA & Ecuador & 5,263 & 1,065 & 6,328 & 2,721 & 9,049 \\
\hline $\mathrm{CA}$ & El Salvador & 404 & 395 & 799 & 3,935 & 4,734 \\
\hline $\mathrm{CA}$ & Guatemala & 1,697 & 218 & 1,915 & 2,967 & 4,882 \\
\hline SA & Guyana & 5,324 & 252 & 5,576 & 3,192 & 8,768 \\
\hline $\mathrm{CA}$ & Honduras & 1,189 & 595 & 1,784 & 2,934 & 4,718 \\
\hline NA & Mexico & 1,195 & 721 & 1,916 & 18,155 & 20,071 \\
\hline $\mathrm{CA}$ & Nicaragua & 867 & 410 & 1,277 & 1,646 & 2,923 \\
\hline $\mathrm{CA}$ & Panama & 3,256 & 664 & 3,920 & 10,551 & 14,471 \\
\hline SA & Paraguay & 2,193 & 1,215 & 3,408 & 4,290 & 7,698 \\
\hline SA & Peru & 1,480 & 341 & 1,821 & 5,326 & 7,147 \\
\hline SA & Suriname & 2,113 & 210 & 2,323 & 5,571 & 7,894 \\
\hline SA & Uruguay & 3,621 & 5,549 & 9,170 & 10,330 & 19,500 \\
\hline \multirow[t]{10}{*}{ SA } & $\begin{array}{l}\text { Venezuela } \\
\text { (Bolivarian } \\
\text { Republic of) } \\
\text { The Caribbean }\end{array}$ & 1,086 & 581 & 1,667 & 13,049 & 14,716 \\
\hline & $\begin{array}{l}\text { Antigua and } \\
\text { Barbuda }\end{array}$ & 1,003 & 468 & 1,471 & 37,151 & 38,622 \\
\hline & Barbados & 190 & 210 & 400 & 17,398 & 17,798 \\
\hline & Dominica & 5,274 & 553 & 5,827 & 14,661 & 20,488 \\
\hline & $\begin{array}{l}\text { Dominican } \\
\text { Republic }\end{array}$ & 1,980 & 386 & 2,366 & 5,480 & 7,846 \\
\hline & Grenada & 572 & 67 & 639 & 15,444 & 16,083 \\
\hline & Haiti & 668 & 112 & 780 & 576 & 1,356 \\
\hline & Jamaica & 824 & 152 & 976 & 9,723 & 10,699 \\
\hline & $\begin{array}{l}\text { St. Kitts and } \\
\text { Nevis }\end{array}$ & 0 & 0 & 0 & 34,197 & 34,197 \\
\hline & St. Lucia & 3,394 & 108 & 3,502 & 13,018 & 16,520 \\
\hline
\end{tabular}




\section{Table $7 A .2$ (continued)}

\begin{tabular}{|c|c|c|c|c|c|c|}
\hline \multirow[t]{2}{*}{ Region } & \multirow[t]{2}{*}{ Country } & \multicolumn{3}{|c|}{ Potential rural tax base } & \multirow{2}{*}{$\begin{array}{c}\text { Potential } \\
\text { urban tax } \\
\text { base } \\
\text { Urban } \\
\text { land + } \\
\text { structures* }\end{array}$} & \multirow{2}{*}{$\begin{array}{c}\text { Potential } \\
\text { base of } \\
\text { the } \\
\text { property } \\
\text { tax }\end{array}$} \\
\hline & & Cropland & $\begin{array}{l}\text { Pasture- } \\
\text { land }\end{array}$ & $\begin{array}{l}\text { Cropland + } \\
\text { pasture- } \\
\text { land }\end{array}$ & & \\
\hline & The Caribbean & & & & & \\
\hline & St. Vincent & 2,106 & 109 & 2,215 & 10,041 & 12,256 \\
\hline & $\begin{array}{l}\text { Trinidad and } \\
\text { Tobago }\end{array}$ & 444 & 54 & 498 & 13,871 & 14,369 \\
\hline \multicolumn{7}{|c|}{ Regional averages } \\
\hline \multicolumn{2}{|c|}{ Latin America } & 1,973 & 1,114 & 3,086 & 10,608 & 13,695 \\
\hline \multicolumn{2}{|c|}{ Central America (CA) } & 1,848 & 493 & 2,342 & 4,116 & 6,458 \\
\hline \multicolumn{2}{|c|}{$\begin{array}{l}\text { South and North } \\
\text { America (SA and } \\
\text { NA) }\end{array}$} & 1,983 & 1,164 & 3,147 & 11,137 & 14,284 \\
\hline \multicolumn{2}{|c|}{ The Caribbean } & 1,232 & 226 & 1,458 & 5,139 & 6,596 \\
\hline
\end{tabular}

Note: *As computed by Bahl and Wallace (2010). The tax base reported by the WB includes other produced capital that we would not tax (durable goods for example). The WB report follows Kunte et al. (1998), who assume that urban land corresponds to $33 \%$ of the value of structures and, in turn, that structures correspond to $72 \%$ of the value of total capital.

Source: World Bank (2006). 


\section{Table 7A.3 Variable description and data sources}

\begin{tabular}{|c|c|}
\hline Variable & Description and sources \\
\hline \multirow{4}{*}{$\begin{array}{l}\text { Property tax } \\
\text { collections } \\
\text { Fiscal } \\
\text { decentralization }\end{array}$} & Share of property tax collections over GDP (in percentage) \\
\hline & Source: CEPAL \\
\hline & $\begin{array}{l}\text { Share of subnational expenditures over total government } \\
\text { expenditures (in percentage) }\end{array}$ \\
\hline & Source: CEPAL \\
\hline \multirow[t]{2}{*}{$\begin{array}{l}\text { Dependency on } \\
\text { transfers }\end{array}$} & $\begin{array}{l}\text { Share of intergovernmental transfers over total subnational } \\
\text { revenues (in percentage) }\end{array}$ \\
\hline & Source: CEPAL \\
\hline \multirow[t]{2}{*}{ Government size } & Government share of real GDP per capita (in percentage) \\
\hline & Source: Penn World Table, PWT6.3, Heston et al. (2009) \\
\hline \multirow[t]{2}{*}{$\begin{array}{l}\text { Log of per capita } \\
\text { GDP }\end{array}$} & $\begin{array}{l}\text { Based on per capita real GDP (in purchasing power parity, } \\
\text { PPP) }\end{array}$ \\
\hline & Source: Penn World Table, PWT6.3, Heston et al. (2009) \\
\hline $\begin{array}{l}\text { Log of estimated } \\
\text { property tax base }\end{array}$ & $\begin{array}{l}\text { Based on the sum of the potential property tax base } \\
\text { for rural and urban areas, as computed in Appendix } \\
\text { Table 7A. } 2 \text { with data from World Bank (2006). Figures } \\
\text { correspond to year 2000, and are expressed on SUS per } \\
\text { capita }\end{array}$ \\
\hline \multirow[t]{2}{*}{ Urban population } & $\begin{array}{l}\text { Share of the total population living in urban areas (in } \\
\text { percentage) }\end{array}$ \\
\hline & Source: World Development Indicators \\
\hline \multirow[t]{3}{*}{$\begin{array}{l}\text { Competition for } \\
\text { public positions }\end{array}$} & $\begin{array}{l}\text { Competitiveness of Executive Recruitment: extent to } \\
\text { which subordinates enjoy equal opportunities to become } \\
\text { superordinates }\end{array}$ \\
\hline & Source: Polity IV Project. 2009. Political Regime \\
\hline & $\begin{array}{l}\text { Characteristics and Transitions, University of Maryland, } \\
\text { College Park, available at: http://www.bsos.umd.edu/ } \\
\text { cidcm/inscr/polity/index.htm }\end{array}$ \\
\hline \multirow[t]{3}{*}{ Index of democracy } & $\begin{array}{l}\text { POLITY } 2 \text { is a modified version of the POLITY, which } \\
\text { is obtained by subtracting the value of the scaled value } \\
\text { representing AUTOCRATIC (range } 0-10 \text { ) from the } \\
\text { value of DEMOCRATIC (range } 0-10 \text { ) in order to } \\
\text { provide a unified polity scale ranging from }+10 \text { (strongly } \\
\text { democratic) to }-10 \text { (strongly autocratic) }\end{array}$ \\
\hline & Source: Polity IV Project. 2009. Political Regime \\
\hline & $\begin{array}{l}\text { Characteristics and Transitions, University of Maryland, } \\
\text { College Park, available at: http://www.bsos.umd.edu/ } \\
\text { cidem/inscr/polity/index.htm }\end{array}$ \\
\hline \multirow[t]{2}{*}{ Log of population } & Based on population (thousands) \\
\hline & $\begin{array}{l}\text { Source: Penn World Table, PWT6.3, Heston et al. } \\
\text { (2009) }\end{array}$ \\
\hline
\end{tabular}


Table 7 A.3 (continued)

\begin{tabular}{|c|c|}
\hline Variable & Description and sources \\
\hline $\begin{array}{l}\text { Political } \\
\text { competition }\end{array}$ & $\begin{array}{l}\text { It combines two concepts: the degree of } \\
\text { institutionalization, or regulation, of political } \\
\text { competition, and the extent of government restriction } \\
\text { on political competition. It ranges from } 1 \text { (suppressed } \\
\text { competition) to } 10 \text { (institutionalized electoral) } \\
\text { Source: Polity IV Project. } 2009 \text {. Political Regime } \\
\text { Characteristics and Transitions, University of Maryland. } \\
\text { College Park, available at: http://www.bsos.umd.edu/ } \\
\text { cidcm/inscr/polity/index.htm }\end{array}$ \\
\hline Openness to trade & $\begin{array}{l}\text { Openness in constant prices: exports plus imports divided } \\
\text { by real GDP per capita; Laspeyres (in percentage) } \\
\text { Source: Penn World Table, PWT6.3, Heston et al. (2009) }\end{array}$ \\
\hline $\begin{array}{l}\text { Price of government } \\
\text { expenditures }\end{array}$ & $\begin{array}{l}\text { PPP over government consumption } \\
\text { Source: Penn World Table, PWT6.3, Heston et al. (2009) }\end{array}$ \\
\hline
\end{tabular}


Table 7A.4 Summary statistics

\begin{tabular}{|c|c|c|c|c|c|c|c|}
\hline \multicolumn{2}{|l|}{ Variable } & \multirow{2}{*}{$\frac{\text { Mean }}{0.39}$} & \multirow{2}{*}{$\begin{array}{r}\text { Std dev. } \\
0.21\end{array}$} & \multirow{2}{*}{$\frac{\text { Min }}{0.06}$} & \multirow{2}{*}{$\frac{\operatorname{Max}}{0.74}$} & \multicolumn{2}{|c|}{ Observations } \\
\hline \multirow{3}{*}{$\begin{array}{l}\text { Property tax } \\
\text { collections }\end{array}$} & overall & & & & & $N=$ & 115 \\
\hline & betw & & 0.20 & 0.12 & 0.64 & & 9 \\
\hline & within & & 0.06 & 0.16 & 0.52 & $\mathrm{~T}$-bar $=$ & 12.8 \\
\hline \multirow{3}{*}{$\begin{array}{l}\text { Fiscal } \\
\text { decentralization }\end{array}$} & overall & 21.93 & 13.86 & 0.65 & 47.16 & $N=$ & 115 \\
\hline & between & & 13.71 & 1.17 & 44.76 & $\mathrm{n}=$ & 9 \\
\hline & with & & 3.78 & 5.65 & 30.15 & $\mathrm{~T}-\mathrm{bar}=$ & 12.8 \\
\hline \multirow{3}{*}{$\begin{array}{l}\text { Dependency on } \\
\text { transfers }\end{array}$} & overall & 58.62 & 19.09 & 20.53 & 93.04 & $N=$ & 115 \\
\hline & betw & & 1 & 6 & 89.46 & $\mathrm{n}=$ & 9 \\
\hline & wit! & & & & & $\mathrm{T}$-bar = & 12.8 \\
\hline \multirow{3}{*}{ Government size } & over & 15.22 & 2.92 & 11 & 22 & $N=$ & 115 \\
\hline & betw & & 2.55 & 12 & & $\mathrm{n}=$ & 9 \\
\hline & with & & 1.74 & 8 & 19. & $\mathrm{~T}$-bar $=$ & 12.8 \\
\hline \multirow{3}{*}{$\begin{array}{l}\text { Log of per capita } \\
\text { GDP (PPP) }\end{array}$} & over & 8.86 & 0.42 & & & $\mathrm{~N}=$ & 115 \\
\hline & betw & & 0. & 8 & 9. & $\mathrm{n}$ & 9 \\
\hline & with & & 0.19 & 8.37 & 9. & $\mathrm{~T}-1$ & 12.8 \\
\hline \multirow{3}{*}{$\begin{array}{l}\text { Per capita GDP } \\
\text { (PPP) }\end{array}$} & overall & 7,690 & 3,511 & 3,164 & 48 & $\mathrm{~N}=$ & 115 \\
\hline & bet & & & & & $\mathrm{n}$ & 9 \\
\hline & wi & & 1 & & & T. & 12.8 \\
\hline \multirow{3}{*}{$\begin{array}{l}\text { Log of estimated } \\
\text { property tax base } \\
\text { (per capita USS } \\
\text { of year } 2000 \text { ) }\end{array}$} & ove & 2.48 & 0.50 & 1.41 & 3.21 & $N=$ & 115 \\
\hline & beth & & & 1.41 & 3. & $\mathrm{n}=$ & 9 \\
\hline & within & & 0.0 & 2.48 & 2.48 & $\mathrm{~T}-\mathrm{bar}=$ & 12.8 \\
\hline \multirow{3}{*}{$\begin{array}{l}\text { Urban } \\
\text { population }\end{array}$} & ove & 74.2 & 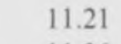 & 6 & & $\mathrm{~N}$ & 115 \\
\hline & bet & & & & & $\mathrm{n}$ & 9 \\
\hline & & & & & & $\mathrm{T}$-bar $=$ & 12.8 \\
\hline \multirow{3}{*}{$\begin{array}{l}\text { Competition for } \\
\text { political positions }\end{array}$} & & 2.71 & & & & $N=$ & 115 \\
\hline & betv & & 0 & & & $\mathrm{n}=$ & 9 \\
\hline & witl & & & & & $\mathrm{T}$-bar = & 12.8 \\
\hline \multirow{3}{*}{$\begin{array}{l}\text { Index of } \\
\text { democracy }\end{array}$} & over & 7.44 & 1.81 & 0. & 10.00 & $N=$ & 115 \\
\hline & bet & & & & & $\mathrm{n}=$ & 9 \\
\hline & wit & & 1 & 2. & 2 & $\mathrm{~T}$-bar $=$ & 12.8 \\
\hline \multirow{3}{*}{$\begin{array}{l}\text { Log of } \\
\text { population }\end{array}$} & over & 10.27 & 0.96 & 8.60 & 12. & $N=$ & 115 \\
\hline & bet & & 1.11 & 8.71 & & $\mathrm{n}=$ & 9 \\
\hline & & & 0. & 10 . & & $\mathrm{T}$-bar = & 12.8 \\
\hline \multirow{3}{*}{$\begin{array}{l}\text { Political } \\
\text { competition }\end{array}$} & overall & 8.27 & 0.99 & 7.00 & 0 & $\mathrm{~N}=$ & 115 \\
\hline & between & & 0.87 & 7.00 & 9. & $\mathrm{n}=$ & 9 \\
\hline & witl & & 0.67 & 7.16 & 9. & $\mathrm{~T}$-bar $=$ & 12.8 \\
\hline \multirow{3}{*}{$\begin{array}{l}\text { Openness to } \\
\text { trade }\end{array}$} & overall & 50.74 & 21.99 & 21.22 & 138.80 & $N=$ & 115 \\
\hline & een & & 24.44 & & 107.66 & $\mathrm{n}=$ & 9 \\
\hline & with & & 8.86 & 28.20 & 81.89 & $\mathrm{~T}$-bar $=$ & 12.8 \\
\hline \multirow{3}{*}{$\begin{array}{l}\text { Price level of govt } \\
\text { expenditures }\end{array}$} & overall & 40.02 & 15.67 & 14.04 & 75.44 & $\mathrm{~N}=$ & 115 \\
\hline & between & & 11.87 & 18.07 & 55.91 & $\mathrm{n}=$ & 9 \\
\hline & within & & 10.76 & 6.34 & 66.38 & $\mathrm{~T}$-bar $=$ & 12.8 \\
\hline
\end{tabular}

